UCD CENTRE FOR ECONOMIC RESEARCH

WORKING PAPER SERIES

2019

Did Bank Lending Stifle Innovation in Europe During the Great Recession?

Oana Peia, University College Dublin Davide Romelli, Trinity College Dublin

WP19/26

November 2019

UCD SCHOOL OF ECONOMICS

UNIVERSITY COLLEGE DUBLIN

BELFIELD DUBLIN 4 


\title{
Did bank lending stifle innovation in Europe during the Great
}

\section{Recession?*}

\author{
Oana Peia ${ }^{\dagger}$ \\ Davide Romelli \\ University College Dublin \\ Trinity College Dublin
}

\begin{abstract}
Using the 2008-09 Global financial crisis and the 2012 Euro area sovereign debt crisis as natural experiments, we investigate the effects of contractions in credit supply on R\&D spending in a large sample of European firms. Our identification strategy exploits differences in financial constraints across firms, as well as the cross-industry variation in dependence on external finance, to identify a causal effect of bank credit supply on firm investment in innovation. We show that firms that are more likely financially constrained, in industries more dependent on external finance, have a disproportionally lower growth rate of $\mathrm{R} \& \mathrm{D}$ spending, as well as lower $\mathrm{R} \& \mathrm{D}$ intensity and share of $\mathrm{R} \& \mathrm{D}$ investment in total investment during periods of tight credit supply. These results are robust to different proxies of financial constraints, model specifications and fixed-effects identification strategies.
\end{abstract}

Keywords: financial frictions, investment, innovation, $\mathrm{R} \& \mathrm{D}$ spending.

JEL Classification: O30, G21, I22.

\section{Introduction}

European countries have experienced two crisis episodes in rapid succession: the first corresponding to the 2008-09 Global financial crisis and the second to the 2012 Sovereign debt crisis. Both episodes were accompanied by large contractions of bank credit, as depicted in Figure 1, which shows the evolution of two indicators of credit supply from the ECB's Bank

\footnotetext{
${ }^{*}$ We would like to thank Falko Fecht, Steven Ongena, Jeffrey Wooldridge, Razvan Vlahu, seminar participants at UCD School of Economics, UCD Smurfit Business School and University of Limerick, as well as participants to the 2018 ERMAS conference, the 2019 Financial Engineering and Banking Society Conference and the $34^{\text {th }}$ Annual Congress of the European Economic Association.

${ }^{\dagger}$ Corresponding author. E-mail: oana.peia@ucd.ie.
} 
Figure 1: Contractions in credit supply in Europe

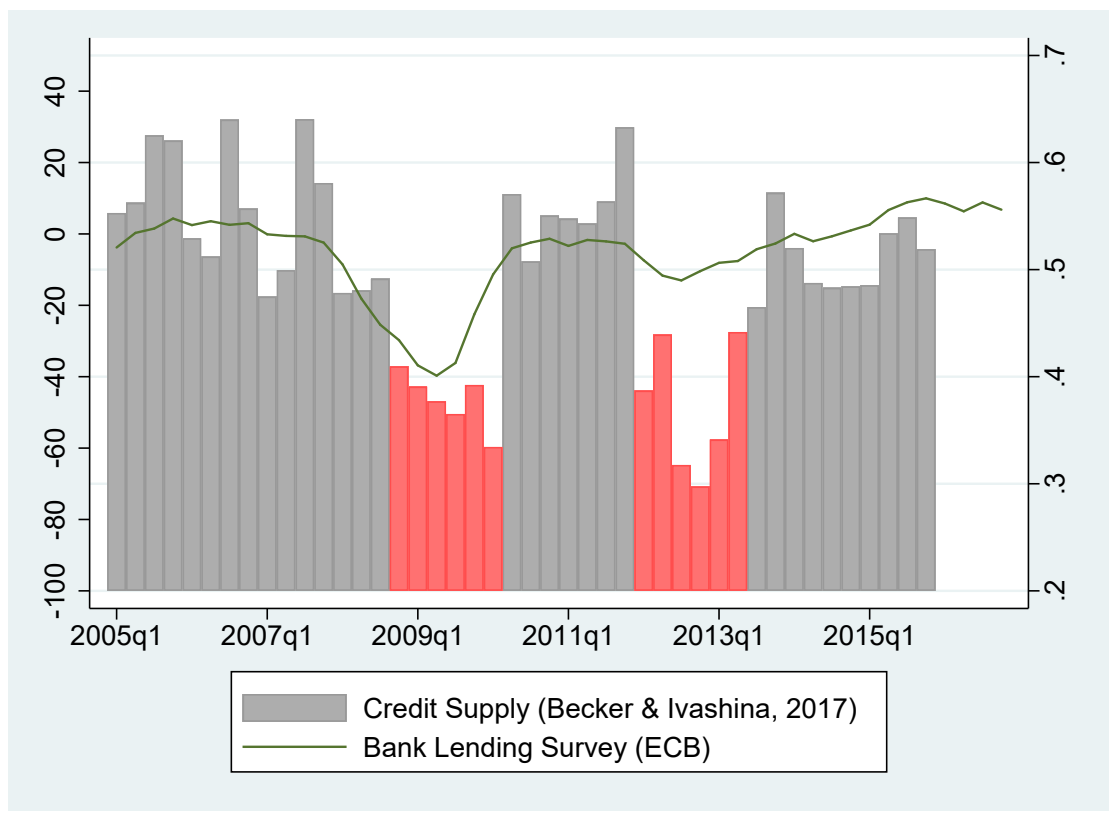

The bar lines (right axis) show a measure of credit supply constructed by Becker \& Ivashina (2017) as the fraction of firms receiving new bank loans among all firms that raise new debt in a given quarter. A lower fraction of firms issuing bank loans as compared to bond financing is indicative of a contraction in credit supply, after controlling for the demand for credit. The line (left axis) is an index based on a survey of banks conducted by the European Central Bank that shows the difference between the share of banks reporting easing of credit standards and the share reporting tightening.

Lending Survey (Scopel et al. 2016) and Becker \& Ivashina (2017). In this paper, we examine whether these periods of tight credit supply caused European firms to invest less in innovation.

The importance of bank credit for financing innovation is not straightforward. A long-standing argument in the finance literature is that, due to their uncertain outcome, informational problems and lack of collateral value, investments in innovation are best financed through equity or internal funds (see Hall et al. 2010). ${ }^{1}$ Yet, bank credit might matter in periods of tight credit supply, even if firms do not directly finance investment in innovation through debt. The argument is that, when bank credit supply is low, firms that are unable to access other sources of external finance will divert any available funds towards more "essential" investments (see Nanda \& Nicholas 2014). We sketch this argument theoretically by exploring the idea that firms' reliance on external financing is a technological characteristic intrinsic to the production process that is stable, at the industry level, across time (see Rajan \& Zingales 1998). We then

\footnotetext{
${ }^{1}$ A large literature looking mainly at listed firms supports this claim. For example, Brown et al. (2009) show that young, high-tech, publicly-traded firms in the United States finance their R\&D investment almost entirely through internal cash flows and external equity markets. Similarly, Brown et al. (2012) look at European listed firms and highlight the sensitivity of R\&D to stock issues after controlling for internal funds. Acharya \& $\mathrm{Xu}(2017)$ underline the importance of public equity markets in financing innovation in a sample of listed US firms. Brown et al. (2017) show that stock market development is associated with faster growth in high-tech industries that are more R\&D intensive, while credit markets only matter for the growth of industries that rely extensively on external finance to fund their fixed capital investments.
} 
show that, when R\&D investment cannot be collateralized, tighter credit constraints will cause firms in industries that generally depend more on external finance to invest disproportionally less in innovation.

We then employ the 2008-09 Global financial crisis and the 2012 Euro area sovereign debt crisis as natural experiments to investigate the effect of contractions in credit supply on investments in Research and Development (R\&D). We combine various sources to construct a large firmlevel dataset of European companies that report data on $R \& D$ spending over the period 2006-2016. The particularity of our data is that it contains both privately held, small firms, as well as large publicly listed European firms across 12 countries.

Our identification strategy exploits three sources of variation in financial conditions. At the firm-level, we employ several proxies of financial constraints including differences among private and publicly listed firms and small and large firms. ${ }^{2}$ We argue that the extent to which the severity of firm financial constraints matters for R\&D spending depends on how reliant firms are on obtaining external financing, in general. We capture this latter characteristic using the Rajan \& Zingales (1998) industry-level index of dependence on external finance. Finally, at the aggregate level, we employ the time and cross-country variation in credit conditions in Europe as an exogenous shock to credit supply. The main argument is that, if bank credit matters for investments in innovation, then, in periods in which credit supply is low, firms that face tighter financial frictions will invest disproportionally less in innovation.

Our results point to a strong effect of contractions in credit supply on firm investment in innovation. In a difference-in-difference framework, we find that firms that are more financially constrained invest less in R\&D during periods of tight credit supply, in particular in industries that have an above the median dependence on external finance. Our main measure of financial constraints is a firm's ability to obtain external financing from other sources when the banking sector is in distress, which we proxy by its status as a private or publicly listed company. Alternatively, we employ other proxies such as firm size or its financial position captured by liquidity or leverage ratios.

We capture investment in innovation using three measures: the growth rate of $\mathrm{R} \& \mathrm{D}$ spending, the growth rate of $R \& D$ to sales and the share of $R \& D$ in total investment. The disruption in

\footnotetext{
${ }^{2}$ Farre-Mensa \& Ljungqvist (2016) show that differences between private and public firms, as well as very small and large firms, are better at capturing financial constraints at the firm level, as compared to classical proxies that rely on firm financial statements, changes in investment plans or the ability to pay dividends. They show that when increases in taxes create an exogenous demand for bank credit, even firms that are classified as financially constrained according to five widely-used proxies are, in fact, able to borrow as a response to increases in corporate taxes. They show that privately-held small firms or listed firms close to default are the only ones unresponsive to the tax changes, suggesting that they indeed have difficulties raising external finance.
} 
credit supply had an economically significant impact along all these measures. For example, private firms in industries highly dependent on external finance have a $2.6 \%$ lower growth rate of $\mathrm{R} \& \mathrm{D}$ spending, a $3.3 \%$ lower $\mathrm{R} \& \mathrm{D}$ intensity growth rate and a $10 \%$ lower share of $\mathrm{R} \& \mathrm{D}$ in total investment during periods of tight credit supply.

These results are robust to a wide-array of model specifications. First, we saturate the model with fixed effects to mitigate any concerns that the results are driven by patterns in $R \& D$ across firms and time, as well as aggregate demand conditions. In particular, apart from country, time and industry fixed effects, we also control for industry-year, country-year, as well as industry-country fixed effects. Next, we control for several firms characteristics that can be correlated with investment behavior as well as the treatment condition, i.e., differences in financial constraints. We also account for the fact that firms may want to smooth R\&D investment by splitting the sample into industries with high versus low R\&D intensity. We show that financial constraints matter particularly among industries with low R\&D intensity, as these firms are more likely to shift away from high-risk $R \& D$ projects. Finally, we perform propensity score matching to ensure that firms in the treated and control samples are comparable, and we check the robustness of our results to several falsification strategies.

The remainder of this paper is organized as follows. Section 2 discusses the relation with previous literature, while section 3 presents a stylized theoretical argument that guides our empirical strategy. Section 4 discusses the identification strategy, section 5 presents the data and descriptive statistics, and section 6 the results. Finally, section 7 concludes.

\section{Relation to literature}

Our work is related to a growing literature that investigates the consequences of the contraction in credit supply in Europe over the past decade. Bentolila et al. (2015) document that Spanish firms borrowing from banks heavily exposed to the 2008 Global financial crisis experienced significantly larger drops in employment, while Garicano \& Steinwender (2016) find that they also shifted the types of investments undertaken from longer-term investments to short-term ones. Similarly, Cingano et al. (2016) show that Italian firms that had relationships with banks heavily exposed to the interbank market experienced a larger drop in investment and employment (see also Balduzzi et al. 2017, Bofondi et al. 2018). Ferrando et al. (2017) use firms' self-reported measures of financial constraints collected by the ECB SAFE survey to show that firms in countries severely affected by the 2012 Sovereign debt crisis faced lower access to credit. We complement these findings by providing the first cross-country study 
of how these two crisis episodes in Europe have impacted not only the volume, but, more importantly, the composition of corporate investment, by showing that they disproportionally discourage investments in innovation.

This paper is also related to a growing literature that suggests that bank credit is an important source of capital, even for firms engaged in innovation. Classical arguments, discussed extensively in early surveys such as Hall et al. (2010), view a limited role of banks in financing innovation due to the high uncertainly and low collateral value of this type of investment. However, more recent surveys, such as Kerr \& Nanda (2015), argue that recent work provides a more nuanced evidence supporting a role for debt financing. For example, Cornaggia et al. (2015) and Chava et al. (2013) show that the interstate deregulations in the US during the 1980s and 1990s increased innovation output by small, private firms, who are also likely to depend more on bank financing. Robb \& Robinson (2014) show that bank finance is an important source of startup capital in a large sample of US start-ups. Benfratello et al. (2008) show that local bank development in Italy increases the probability that companies invest in innovation, in particular among smaller firms. Aghion et al. (2012) use a sample of French firms over 1994-2004 to show that R\&D investment is, in general, negatively related to sales, implying it is countercyclical. However, in periods when firms face tighter credit constraints (captured by a failure to pay trade creditors), R\&D investment becomes procyclical, i.e., it is positively related to sales. This suggests that financial frictions can hinder investment in innovation. Closely related to our work is also Ridder (2017) who employs syndicated loan data to show that large US firms borrowing from banks exposed to the 2008 Global financial crisis have invested less in R\&D.

Another approach in linking access to finance to innovative behavior is to look at differences between private and listed firms. The argument is that access to equity markets should facilitate spending on $R \& D$ as this is a better source of external financing for such risky, uncollateralized investment (Brown et al. 2009). Indeed, Acharya \& Xu (2017) and Feldman et al. (2018) find that going public increases R\&D spending and patent output. Bernstein (2015), on the other hand, finds that the transition to public equity markets leads firms to reposition their R\&D investments towards more conventional projects. Finally, in a differencein-difference set-up similar to the one in this paper, Nanda \& Nicholas (2014) find that private firms operating in US counties with higher bank distress during the 1930's Great Depression were less innovative than public ones, suggesting that periods of tight credit supply can affect innovation.

Finally, our work is also related to recent research looks at the causes of the sustained drop 
in productivity that follows episodes of systemic bank distress (Reinhart \& Rogoff 2014). While persistent demand shortfalls have undoubtedly played an important role, the leading theoretical argument points to supply-side factors. For instance, Anzoategui et al. (2017) build a macroeconomic model of the US economy, and show that the productivity slowdown following the Global financial crisis was caused by the drop in R\&D investment and technology adoption that followed the crisis. Duval et al. (2019) also investigate the productivity slowdown in a cross-section of countries that were hit by the 2008-09 Global financial crisis and show that financially fragile firms experienced a lower total factor productivity growth and cut back more on intangible investment. Our paper complements these previous works by explicitly linking financial conditions to firms' incentives to engage in R\&D investment.

\section{Theoretical argument}

This section sketches a simple theoretical argument that is used to guide our subsequent empirical exercise. The model is based on Aghion et al. (2010) and Aghion et al. (2012) and makes a distinction between two types of investment projects available to a firm, i.e., physical capital or R\&D projects.

Set-up. The economy is populated by a continuum of entrepreneurs (firms) who live two periods and maximize their end-of-life wealth. We assume entrepreneurs have no initial wealth and some amount of external financing $I$ is required to initiate investment projects. Under the usual assumption of information asymmetries, we model credit market imperfections as a simple credit multiplier, such that if a firm wants to invest $I$ it must have assets of at least $\nu I$, with $\nu \in(0,1) .{ }^{3}$ Given this initial level of borrowing, the firm can invest in two types of capital. Physical capital, denoted by $k$, yields a short-run profit $a_{t} k$ at the end of the first period and has an irreversible adjustment cost of $\frac{1}{2} d k^{2}$. Investment in $\mathrm{R} \& \mathrm{D}$, denoted by $z$, takes longer to becomes productive and yields an output $E\left(a_{t+1}\right) z$ in period $t+1$ at $\operatorname{cost} \frac{1}{2} c z^{2}$. Investment in R\&D differs from physical capital in two ways. First, its output is uncertain as it depends on the expected productivity at time $t=1$, denoted by $E\left(a_{t+1}\right)$. Second, in line with empirical arguments, we assume that $R \& D$ investment cannot be easily pledged as collateral, as its output is generally an intangible asset (Hall et al. 2010). As such, the firm's borrowing constraint is determined by its investment in physical capital:

$$
I \leq \tau a_{t} k
$$

\footnotetext{
${ }^{3}$ See Aghion et al. (1999) for a rationalization of this result under costly state verification and moral hazard.
} 
where $\tau \equiv \frac{1}{\nu} \geq 1$ is the credit multiplier.

Assuming entrepreneurs are risk-neutral and do not discount the future, they choose the optimal investment in physical capital and $\mathrm{R} \& \mathrm{D}$ to maximize their profits as follows:

$$
\begin{aligned}
& \underset{k, z}{\operatorname{Max}} \quad a_{t} k+E\left(a_{t+1}\right) z-\frac{1}{2} d k^{2}-\frac{1}{2} c z^{2} \\
& \text { subject to: } k+z \leq \tau a_{t} k .
\end{aligned}
$$

Depending on whether the borrowing constraint binds or not, the optimization problem above yields two cases. First, consider firms for which the constraint is not binding, i.e., firms whose reliance on external finance is generally low. We interpret this case as firms in industries that generally have a low dependence on obtaining external finance. ${ }^{4}$

Low dependence on external finance. The firm's optimization problem when the constraint is not binding yields the first-best allocation of investment projects as follows:

$$
\begin{aligned}
k & =a_{t}, \\
z & =E\left(a_{t+1}\right) .
\end{aligned}
$$

Thus, in the case of firms that have a low dependence on external finance, the optimal level of investment in $\mathrm{R} \& \mathrm{D}$ only depends on the expected productivity of the project and not on the credit constraint. ${ }^{5}$

High dependence on external finance. Consider now the case of firms that rely extensively on obtaining external finance, for which the borrowing constraint is more is likely to bind. In this case, we can write the borrowing constraint as $z=\left(a_{t} \tau-1\right) k$ and the firm's constrained maximization problem yields: ${ }^{6}$

$$
z=\frac{\left(a_{t} \tau-1\right)\left[a_{t}+E\left(a_{t+1}\right)\left(a_{t} \tau-1\right)\right]+1}{1+\left(a_{t} \tau-1\right)^{2}}
$$

\footnotetext{
${ }^{4}$ Rajan \& Zingales (1998) argue that, for technological reasons innate to the production process, firms in certain industries incur higher up-front costs and require more external capital, making them more dependent on obtaining external financing. This industry characteristic has been widely employed in the finance literature and has been shown to be stable across countries and time (see, among others, Manova \& Yu 2016).

${ }^{5}$ Under additional assumptions about the dynamics of the productivity process, Aghion et al. (2012) show that a similar model can generate countercyclical R\&D dynamics, i.e., unconstrained firms invest more in R\&D during recessions. As our identification strategy exploits differences between constrained and unconstrained firms, this possibility only reinforces the effect we aim to uncover empirically.

${ }^{6}$ The credit constraint is binding whenever the equilibrium value of $\mathrm{R} \& \mathrm{D}$ investment is higher that $\left(a_{t} \tau-1\right) k$, i.e. $E\left(a_{t+1}\right)>\left(a_{t} \tau-1\right) a_{t}$.
} 
which implies that:

$$
\frac{\partial z}{\partial \tau}=\frac{a_{t}\left(a_{t} \tau-1\right)\left(2 E\left(a_{t+1}\right)-a_{t}^{2} \tau\right)}{\left(1+\left(a_{t} \tau-1\right)^{2}\right)^{2}}>0
$$

which is positive as $a_{t} \tau-1>0$, by construction, and $2 E\left(a_{t+1}\right)-a_{t}^{2} \tau>0$ if the credit constraint is binding. This implies that tightening credit constraints - that is, a reduction in $\tau$ - will lower investment in innovation among firms that rely heavily on external finance to finance their investment projects. Moreover, the tighter these constraints are, the lower will be, both the level, as well as the share of R\&D in total investment. ${ }^{7}$

Empirical implications. Based on the simple theoretical model argument presented in this section, we expect that contractions in credit supply will lower investment in R\&D among credit constrained firms, in particular in industries that depend more on external financing.

\section{Identification strategy}

Our identification strategy exploits differences in financial constraints across firms and industries, as well as the variation in aggregate credit supply. As such, isolating movements in loan credit supply in Europe over the period 2006-2016 is crucial to our analysis. We use the Global financial crisis and Euro area sovereign debt crisis as natural experiments. There is, by now, extant evidence that these two episodes were accompanied by sharp contractions in credit supply. Several recent papers using credit registry data show that distressed banks decreased credit supply and this affected firm investment. ${ }^{8}$ Identification employing credit registry data is obtained from firms that borrow from multiple banks over a short period of time, which is generally a very small percentage of firms. Moreover, the availability of such data is limited to a few countries.

An alternative approach to identifying credit supply shocks is proposed in Becker \& Ivashina (2014). They identify movements in loan supply in a time-series context by examining the substitution between bank credit and public debt for firms that raise external finance. The argument is that, conditional on firms raising external finance, a substitution from bank credit to bond financing is evidence of a shift in bank credit supply. Using this methodology for a large sample of European firms, Becker \& Ivashina (2017) identify two time frames that correspond to a contraction in corporate credit supply in Europe, namely 2008Q4-2010Q1 and

\footnotetext{
${ }^{7}$ The share of R\&D in total investment is $\frac{z}{k+z}=\frac{\left(a_{t} \tau-1\right) k}{k+\left(a_{t} \tau-1\right) k}=1-\frac{1}{a_{t} \tau}$, which is obviously increasing in $\tau$. This implies that changes in credit conditions have a larger impact in investments in innovation. The intuition for this result follows naturally from the binding borrowing constraint, $z=\left(a_{t} \tau-1\right) k$, whereby an increase in $\tau$ increases $z$ for the same level of $k$.

${ }^{8}$ For example, see Cingano et al. (2016) and Balduzzi et al. (2017) for evidence for Italy, Iyer et al. (2014) for Portugal, or Garicano \& Steinwender (2016) and Bentolila et al. (2015) for Spain.
} 
2012Q1-2013Q2, respectively. These periods also coincide with the contraction in credit supply identified by the survey measure collected by the European Central Bank, which directly asks banks whether they tightened their lending standards. Figure 1 in the Introduction presents the evolution of both these measures between 2005 and 2015. Based on this evidence, we define a dummy variable, called Credit that takes the value 1 in the years 2008-2010 and 2012-2013, in order to capture periods of contraction in credit supply across the European countries considered. ${ }^{9}$

Given this variation in credit supply over the period considered, we then exploit the cross-firm severity of financial constraints and cross-industry dependence on external finance to highlight a causal impact of bank credit on firm investment in innovation. Our baseline model is as follows:

$$
Y_{i, t}=\beta_{0}+\beta_{1} \text { FinConst }_{i} \times \text { Credit }_{t-1}+\beta_{2} \text { FinConst }_{i}+\beta_{3} \text { Credit }_{t-1}+\theta^{\prime} X_{c, i, j, t}+\epsilon_{i t}
$$

where $Y_{i, t}$ is the measure of innovation activity for firm $i$ in industry $j$ in country $c$ at time t, FinConst ${ }_{i}$ is a firm-level proxy of financial constraints and Credit $_{t-1}$ is a dummy variable taking the value one for periods of low credit supply as defined above. We consider the effect of a contraction in credit supply in year $t$ on the one period ahead investment in innovation, as $R \& D$ spending is well-known to be more persistent than capital investment and to respond to macroeconomic conditions with a lag (Bloom 2007). $X_{c, i, j, t}$ is a vector of control variables that includes firm-specific accounting measures and an array of fixed effects.

In baseline regressions, we include time, country and industry fixed effects to eliminate Europewide patterns in aggregate investment in a given year, as well as country- or industry-specific time-invariant factors. We also gradually saturate the model with other two-way fixed effects such as country-industry fixed effects that allow us to obtain identification from the variation within industries in a country or country-time fixed effects that shut down macroeconomic and demand conditions in a country, in a given year. Finally, industry-year dummy are introduced to account for industry-specific fluctuations in, for example, demand or technological advancements. This wide-array of fixed effects reduces concerns of omitted variable bias and allows us to isolate the impact of financial conditions on firm investment in innovation.

We estimate the model in Eq. (4) separately for industries that have a below and above the median dependence on external finance. As suggested by the theoretical argument in the previous section, firms in industries with a high dependence on external finance are more likely

\footnotetext{
${ }^{9}$ As the non-Eurozone countries in our sample were less affected by the Sovereign debt crisis, the dummy takes the value of zero in the 2012-2013 period for Denmark, Sweden and the UK.
} 
to rely heavily on borrowing to finance their investment projects, and, as such, will respond more to a drop in credit supply. Industry dependence on external finance is defined following the classical work by Rajan \& Zingales (1998) as a technological characteristic innate to the production process, whereby firms in certain industries incur higher up-front costs and require more external capital. Kroszner et al. (2007), Ranciere et al. (2008), Claessens \& Laeven (2003), Chor \& Manova (2012), among others, argue that this measure varies substantially more across industries than across firms within an industry, and the hierarchy of sectors is quite stable over time and countries.

\section{Data}

We obtain data from various databases provided by Bureau van Dijk to construct a unique dataset composed of firm-level observations on R\&D spending for a sample of European countries. Most of the data obtained comes from the ORBIS Europe database, which we complement with country-specific datasets, such as AIDA for Italy, DIANE for France and FAME for UK and Ireland. ${ }^{10}$ These datasets include information on both listed and unlisted firms collected from various country-specific sources, such as national registries and annual reports. While the ORBIS dataset contains data for many European countries, its coverage is extremely uneven, with most countries reporting information on very few firms. After extensive checking of the data, we retain a sample of 12 countries with sufficiently good coverage and data quality for the main variable used in our analysis, namely, Research and Development spending. We collect information for the time frame 2006-2016 for most countries. We include a sample of both manufacturing and service industries corresponding to the two-digit industry codes 10-82 in NACE Rev.2. This excludes farming, extraction and financial sectors, as well as non-market services. We also exclude Scientific R\&D industries (NACE Rev.2 code 72). All variables are deflated by applying local currency deflators at the industry level obtained from OECD STAN (ISIC 4 version). We also restrict our analysis to firms that report more than four years of $R \& D$ data over the period considered.

Table 1 presents the resulting sample of countries along with some summary statistics and checks on the quality of the data. Overall, while the number of firms reporting R\&D expenditure varies across countries, the representativeness of the sample in terms of R\&D coverage is rather high. Column 1 reports the total number of firm-year observations in each country, while column 2 shows the percentage of private firms in an average year. There is a wide range

\footnotetext{
${ }^{10}$ As discussed in Kalemli-Ozcan et al. (2015), the coverage in ORBIS Europe and the various country-specific databases does not perfectly overlap, with the latter containing more complete firm-level information.
} 
of data coverage even in our restricted sample, with some countries mainly reporting data for listed firms. Italy and France have the highest coverage of firms, with a large percentage of private firms, while Finland has the lowest percentage of private firms in the sample. There is a total of close to 1.8 million firms-year observations, with an average of $34 \%$ of private firms across countries. To gauge the representativeness of this sample, Column 3 reports the ratio of the total sales of firms in the ORBIS sample to total output at the country level reported by the OECD, while Column 4 relates the total R\&D expenses of the firms in our sample to the total R\&D at the country level from the OECD ANBERD database. Our sample covers on average $37 \%$ of the output produced in a given country in 2013, but as high as $75 \%$ of the total R\&D. As such, the ORBIS data in our sample captures the bulk of aggregate R\&D as reported by the OECD.

Table 1: Sample and data coverage

\begin{tabular}{lcccc}
\hline Country & $\begin{array}{c}\text { Observa- } \\
\text { tions }\end{array}$ & $\begin{array}{c}\text { Percentage of } \\
\text { private firms }\end{array}$ & $\begin{array}{c}\text { Ratio of sample revenue } \\
\text { to total revenue }\end{array}$ & $\begin{array}{c}\text { Ratio of sample } \\
\text { R\&D to total R\&D }\end{array}$ \\
\hline Belgium & 995 & 0.079 & 0.16 & 0.31 \\
Denmark & 830 & 0.036 & 0.04 & 0.57 \\
Spain & 930 & 0.043 & 0.21 & 0.31 \\
Finland & 1,020 & 0.039 & 0.44 & 1.04 \\
France & $1,201,323$ & 0.995 & 0.87 & 0.82 \\
Germany & 7,093 & 0.364 & 0.38 & 1.11 \\
Greece & 1,595 & 0.065 & 0.19 & - \\
Italy & 521,673 & 0.997 & 0.54 & 0.49 \\
Luxembourg & 361 & 0.114 & 0.83 & - \\
Netherlands & 1,006 & 0.056 & 0.26 & 0.77 \\
Sweden & 8,215 & 0.584 & 0.09 & 0.89 \\
UK & 25,974 & 0.691 & 0.48 & 0.753 \\
\hline Total/Average & $1,771,015$ & 0.339 & 0.374 & 0.22 \\
\hline
\end{tabular}

The table shows the set of countries used in the analysis. It reports the total number of firmyear observations by country in Column 1, the percentage of private firms in each country in an average year and the ratios of Total sales and R\&D expenses in our sample to total output and total R\&D at the country level, as reported in the ANBERD dataset from the OECD.

We construct three measures that capture the degree of investment in innovation of a firm. The first one is the growth rate of R\&D investment defined as: $g_{i, t}^{R \& D}=\frac{R \& D_{i, t}-R \& D_{i, t-1}}{\frac{1}{2}\left(R \& D_{i, t}+R \& D_{i, t-1}\right)}$. This definition is widely used in the firm dynamics literature, as it delivers a growth rate bounded between -2 and 2, and it accommodates the possibility of an investment of 0 in a given year (see Haltiwanger et al. 2013, Schmitz 2017). The second measure captures R\&D intensity and is computed as the growth rate of $\mathrm{R} \& \mathrm{D}$ to Sales in year $t$, using the same definition of growth rates shown above. Finally, we also look at the share of $\mathrm{R} \& \mathrm{D}$ in Total investment, where Total investment is defined as the annual increase in gross fixed assets plus R\&D spending. In line with the theoretical argument in the previous section, investments in $R \& D$ are more sensitive to credit conditions and we expect that credit constrained firms cut 
down more on this type of investment as compared to capital investment. This definition will also allow us to understand the effect of the crunch in credit supply on the composition of firm investment.

We employ proxies for financial constraints at the firm, industry and country level. As discussed above, we exploit the variation of credit supply at the country level using the indexes constructed by Becker \& Ivashina (2017) and the ECB Bank Lending Survey. At the industry level, we classify industries according to their dependence on external finance following Rajan \& Zingales (1998). This measure is constructed on a sample of US Compustat firms by measuring the level of capital expenditures in excess of firm cash flows. The use of external finance by large listed US firms should reflect their financial needs and, to a lesser extent, frictions in the supply of finance as the US has one of the most developed financial systems in the world. Industry-level measures are obtained by taking the median of the firm-level dependence on external finance in an industry over time. The ranking of US industries then represents a good proxy for ranking industries in all countries. We obtain this measure from Peia (2017) who reconstructs the index of financial dependence for a larger set of industries (see Appendix Table A7).

Identifying financial constraints at the firm level is more confounded. A recent paper by Farre-Mensa \& Ljungqvist (2016) use staggered increases in corporate taxes to show that firms classified as financially constrained behave as unconstrained and can raise external financing when they have the incentives to do so. The argument is that debt offers a tax benefit and increases in taxes should increase a firm's demand for debt. They show that firms that are classified as financially constrained according to five widely-used proxies such as the Kaplan \& Zingales (1997) or Whited \& Wu (2006) index are, in fact, able to borrow as a response to increases in corporate taxes. Privately held, small or listed firms close to default were unresponsive to the tax increases, suggesting that they indeed have difficulties raising external finance. Our main measure of financial constraints at the firm-level is a dummy that distinguishes between private and publicly listed firms. Saunders \& Steffen (2011) and Gao et al. (2013), among others, also argue that privately held firms, particularly those that are relatively small, are substantially more likely to be financially constrained then listed firms. Nonetheless, we employ several other measures of financial constraints as well, including firm size, liquidity and leverage.

Apart from these main variables, we control for other firm-level characteristics, whose definition is detailed in Appendix Table A. Table 2 presents some descriptive statistics of the main firm balance sheet variables employed. We split the sample into private and listed firms. As 
Table 2: Summary statistics

\section{Panel A}

\begin{tabular}{|c|c|c|c|c|c|c|}
\hline & \multicolumn{3}{|c|}{ Private Firms } & \multicolumn{3}{|c|}{ Public Firms } \\
\hline & Mean & Median & Std. Dev. & Mean & Median & Std. Dev. \\
\hline $\mathrm{R} \& \mathrm{D}(€ 1000 \mathrm{~s})$ & 884 & 98 & 2,873 & 76,493 & 6,051 & 277,046 \\
\hline Total Assets (€1000s) & 35,515 & 6,418 & 111,741 & $3,905,383$ & 219,951 & $11,813,522$ \\
\hline R\&D/Total Assets & 0.06 & 0.01 & 0.13 & 0.07 & 0.03 & 0.11 \\
\hline Sales $(€ 1000 \mathrm{~s})$ & 25,063 & 6,029 & 65,889 & $2,940,678$ & 254,167 & $8,024,581$ \\
\hline R\&D/Sales & 0.07 & 0.01 & 0.21 & 0.25 & 0.03 & 1.24 \\
\hline Investment $(€ 1000 \mathrm{~s})$ & 6,728 & 529 & 25,148 & 364,107 & 19,428 & $1,159,706$ \\
\hline Investment/Total Assets & 0.29 & 0.17 & 0.35 & 0.10 & 0.07 & 0.09 \\
\hline Investment/Sales & 0.44 & 0.18 & 0.89 & 0.20 & 0.08 & 0.48 \\
\hline Liquidity & 0.42 & 0.40 & 0.26 & 0.38 & 0.35 & 0.21 \\
\hline Leverage & 0.75 & 0.8 & 0.42 & 0.32 & 0.31 & 0.20 \\
\hline
\end{tabular}

Panel B

\begin{tabular}{lcccccccc}
\hline \hline & \multicolumn{3}{c}{ High financial dependence } & & \multicolumn{3}{c}{ Low financial dependence } \\
\cline { 2 - 3 } Growth rate of $R E D$ & Non Crisis & Crisis & ttest & & Non Crisis & Crisis & ttest \\
Private & 0.01 & -0.028 & 3.952 & & 0.008 & -0.022 & 3.280 \\
Public & 0.05 & 0.038 & 0.592 & & 0.044 & 0.032 & 0.732
\end{tabular}

Panel A presents average values of the analyzed variables over the period 2006-2016. Liquidity is the difference between Current Assets and Current liabilities divided by Total Assets. Leverage is the ratio of Total Liabilities to Total Assets. Panel B presents the average values of R\&D growth for private and public companies during crisis and non-crisis periods, in industries characterized by high and low financial dependence, respectively. High/Low financial dependence refers to industries with an above/below the median dependence on external finance, as measured by the Rajan \& Zingales (1998) index. Non-crisis/Crisis refers to the average R\&D growth rate during years where the Credit dummy is zero/one. ttest is the t-statistic of a t-test on the equality of means between non-crisis and crisis periods.

expected, listed firms tend to be larger and invest more in $\mathrm{R} \& \mathrm{D}$, however R\&D to total assets is, on average, comparable across the two samples. Average R\&D intensity is nonetheless higher among public firms. Interestingly, private firms tend to be more leveraged, while both groups of firms have similar levels of liquidity.

As a first look at the data, Panel B presents a simple split sample analysis where we look at the differences in the growth rate of $R \& D$ investment between private and public firms in industries with a below and above the median level of dependence on external finance. We observe a significant drop in $R \& D$ investment of private firms in the periods with tight credit supply and this significant decrease is present both across industries with a low as well as with a high financial dependence. Public firms also see a drop in investment growth rates, but this is smaller and not statistically different in the two sub-periods. This suggests that, not only the evolution of $R \& D$ investment is, on average, different between periods of tight credit supply, but also that the impact of this credit contraction might be stronger in more credit constrained firms. 
Figure 2: Time-varying effects of credit tightening for private vs listed firms

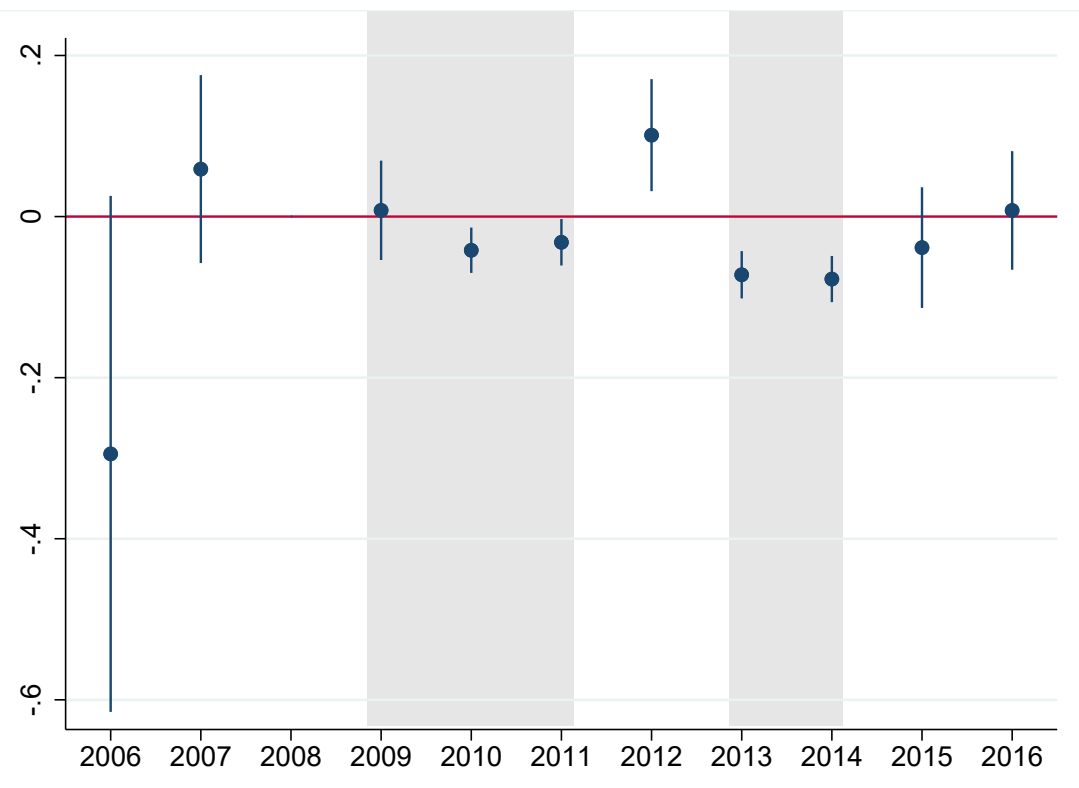

The figure reports coefficients and standard errors from a difference-in-difference equation for the growth rate of $R \& D$ investment regressed on an interaction of private and annual dummies together with country and industry fixed effects. Standard errors are clustered at the country level. Coefficients are measured relative to 2008. 95\% confidence bands are reported.

Another way to validate our identifying assumption, is to check that the differential decrease in investment in R\&D is not present before or after the periods classified as having tight credit supply. This will also allow us to (indirectly) test for the parallel trend assumption and to asses the dynamics of the treatment effect in each year in our sample. To do so, we estimate a difference-in-difference model where we include an interaction of the Private $_{i}$ dummy with year dummies and control for country and industry fixed effects, as follows:

$$
Y_{i, t}=\alpha_{j}+\tau_{c}+\beta_{q} \sum_{q \neq 2008} \mathbb{1}_{t=q} \times \text { Private }_{i}+\theta \text { Private }_{i}+\epsilon_{i t}
$$

where $Y_{i, t}$ is the growth rate of $\mathrm{R} \& \mathrm{D}$ investment. We expect the coefficients of $\beta_{q}$ in the years not corresponding to a contraction in credit supply not to be statistically different from zero once we take into account the overall difference in $\mathrm{R} \& \mathrm{D}$ spending captured by $\theta$. Figure 2 plots the coefficients $\beta_{q}$ from the regression above. It shows a significantly lower growth rate of R\&D investment among private firms during two distinct periods 2010-11 and 2013-14. These two periods correspond to the year after the start of an episode of tight credit supply corresponding to the Becker \& Ivashina (2017) and BLS indices presented in Figure 1. All other years do not show a statistically significant difference. This suggests that the different trends in $R \& D$ spending correspond to periods of tight credit supply. At the same time, Figure 2 reinforces the idea that investment in innovation responds with a lag to aggregate 
macroeconomic conditions as the drop in spending generally occurs one or two years after the start of a contraction in credit supply.

\section{$6 \quad$ Results}

The results from our baseline model in Eq. (4) are presented in Table 3. Panel A shows the estimations for the industries with an above the median dependence on external finance, while Panel B for those below. The measure of financial constraints at the firm level employed in this table is the distinction between private and listed firms, captured by the dummy variable Private $_{i}$. We look at the growth rate of $R \& D$ investment in columns (1)-(2), the growth rate of $R \& D$ intensity in columns (3)-(4) and the share of $R \& D$ in total investment in columns (5)-(6). Across all measures of innovation spending, we find that private firms invest disproportionately less in $\mathrm{R} \& \mathrm{D}$ during periods of tight credit supply, and this difference is significant mainly in industries that are highly dependent on external finance and less so in those below the median level of financial dependence.

Table 3: Baseline results: Investment in innovation and credit constraints

\begin{tabular}{|c|c|c|c|}
\hline Dependent variables: & $\mathrm{R} \& \mathrm{D}$ & $\frac{R \& D}{\text { Sales }}$ & $\frac{R \& D}{\text { Investment }}$ \\
\hline & (1) & $(4)$ & (5) (6) \\
\hline
\end{tabular}

Panel A: Firms in industries with high dependence on external finance

\begin{tabular}{|c|c|c|c|c|c|c|}
\hline Private $_{i} \times$ Credit $_{t-1}$ & $\begin{array}{c}-0.061^{* * *} \\
(0.022)\end{array}$ & $\begin{array}{c}-0.061^{* * *} \\
(0.022)\end{array}$ & $\begin{array}{c}-0.084^{* * *} \\
(0.026)\end{array}$ & $\begin{array}{c}-0.081 * * * \\
(0.027)\end{array}$ & $\begin{array}{c}-0.023^{* *} \\
(0.009)\end{array}$ & $\begin{array}{c}-0.023^{* *} \\
(0.009)\end{array}$ \\
\hline Observations & 46,822 & 46,822 & 46,167 & 46,167 & 35,096 & 35,096 \\
\hline \multicolumn{7}{|c|}{ Panel B: Firms in industries with low dependence on external finance } \\
\hline Private $_{i} \times$ Credit $_{t-1}$ & $\begin{array}{c}-0.023 \\
(0.023)\end{array}$ & $\begin{array}{l}-0.024 \\
(0.022)\end{array}$ & $\begin{array}{l}-0.013 \\
(0.024)\end{array}$ & $\begin{array}{l}-0.015 \\
(0.023)\end{array}$ & $\begin{array}{c}0.001 \\
(0.009)\end{array}$ & $\begin{array}{c}0.001 \\
(0.009)\end{array}$ \\
\hline Observations & 47,549 & 47,549 & 47,115 & 47,115 & 33,471 & 33,471 \\
\hline \multicolumn{7}{|l|}{ Controls: } \\
\hline Private $_{i}$, Credit $_{t-1}$ & Yes & Yes & Yes & Yes & Yes & Yes \\
\hline Country FE & Yes & & Yes & & Yes & \\
\hline Industry FE & Yes & & Yes & & Yes & \\
\hline Time FE & Yes & Yes & Yes & Yes & Yes & Yes \\
\hline Country-industry FE & & Yes & & Yes & & Yes \\
\hline
\end{tabular}

Table presents the estimates of Eq. (4). The dependent variable in columns (1)-(2) is the growth rate of R\&D investment in year $t$, in columns (3)-(4) is the growth rate of the ratio of R\&D to sales, while in columns (5)-(6) it is the share of R\&D to total investment. Panel A includes industries with an above the median dependence on external finance, while Panel B those with below the median dependence. Private $_{i}$ is a dummy for private firms. Credit $t_{t-1}$ is a dummy taking the value one in 2008-2010 and 2012-2013. Standard errors are clustered at the country level. $* / * * / * * *$ represents significance at 10,5 and $1 \%$ level.

We control for industry, time and year fixed effects in the first column for each dependent 
Figure 3: Correlations between treatment condition and firm characteristics

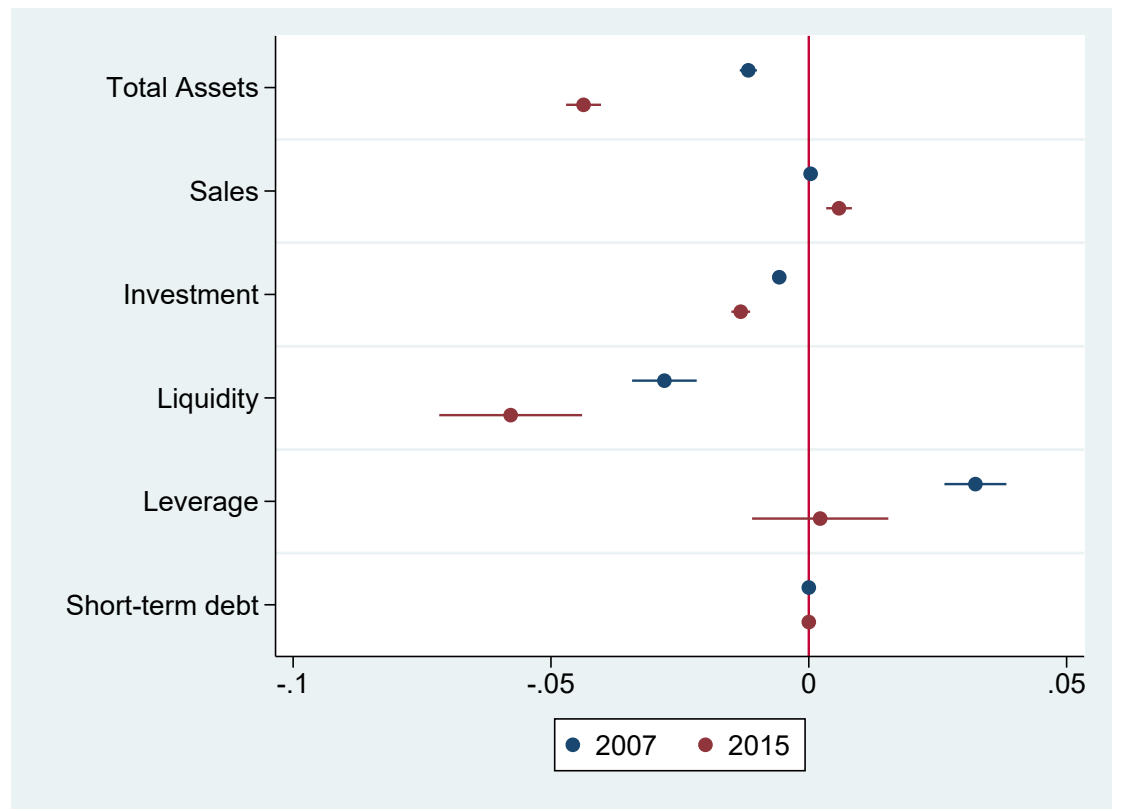

The figure shows coefficient estimates of two cross-sectional OLS regressions in year 2007 and 2015. The dependent variable is Private $_{i}$, a dummy equal 1 if the firm is private. Total Assets is the log of total assets, Sales is the log of sales, Investment is the log of investment measured as the gross change in fixed assets. Liquidity is defined as the difference between current assets and current liabilities scaled down by total assets. Leverage is defined here as the ratio of liabilities to total assets. $5 \%$ confidence intervals are shown.

variable and for country-industry fixed effects in the second one. This latter strategy allows us to obtain identification from the differences between firms in the same industry in a given country and control for time invariant factors that are specific to a certain industry in a country, such as tax benefits for investing in R\&D. Furthermore, we also include industry-year and country-year fixed effects in Appendix Table A1. This controls for any industry-specific demand or technological factors, as well as macroeconomic conditions at the country level in a given year. The wide array of fixed effects allows us to shut down aggregate demand conditions that might affect investments in innovation in a given country or industry at a point in time. Results are mostly consistent under this more econometrically demanding setting, although we lose significance for R\&D growth when we add industry-year fixed effects.

The results in Table 3 point to a disproportionally lower growth rate of $\mathrm{R} \& \mathrm{D}$ investment, $R \& D$ intensity and a lower share of $R \& D$ in total investment among firms that are more likely credit constrained following periods of tight credit supply. The effects are also economically relevant. Private firms have a $2.6 \%$ lower growth rate of R\&D spending (column (2)), a 3.3\% lower R\&D intensity growth (column (4)) and a $10 \%$ lower share of R\&D in total investment. However, one might argue that listed and private firms differ along a set of characteristics that are correlated with their investment behavior. In Figure 3, we show simple cross-sectional 
Table 4: Alternative model: controlling for firm characteristics

\begin{tabular}{|c|c|c|c|c|c|c|}
\hline Dependent variables: & $\begin{array}{l}\mathrm{R} \& \mathrm{D} \\
(1)\end{array}$ & $\begin{array}{l}\frac{R \& D}{\text { Sales }} \\
(2)\end{array}$ & $\frac{R \& D}{\text { Investment }}$ & $\begin{array}{c}R \& D \\
(4)\end{array}$ & $\begin{array}{l}\frac{R \& D}{\text { Sales }} \\
(5)\end{array}$ & $\frac{R \& D}{\text { Investment }}$ \\
\hline Private $_{i} \times$ Credit $_{t-1} \times$ ExtDep $_{j}$ & $\begin{array}{c}-0.010^{* *} \\
(0.004)\end{array}$ & $\begin{array}{c}-0.017^{* * *} \\
(0.004)\end{array}$ & $\begin{array}{c}-0.013^{* *} \\
(0.006)\end{array}$ & $\begin{array}{c}-0.019^{* * *} \\
(0.005)\end{array}$ & $\begin{array}{c}-0.017^{* *} \\
(0.007)\end{array}$ & $\begin{array}{c}-0.007^{*} \\
(0.004)\end{array}$ \\
\hline Total Assets & & & & $\begin{array}{c}0.152 \\
(0.114)\end{array}$ & $\begin{array}{c}0.246^{* *} \\
(0.113)\end{array}$ & $\begin{array}{c}-0.054^{* * *} \\
(0.006)\end{array}$ \\
\hline Sales & & & & $\begin{array}{c}0.051^{* * *} \\
(0.016)\end{array}$ & $\begin{array}{c}-0.224^{* * *} \\
(0.022)\end{array}$ & $\begin{array}{c}0.001 \\
(0.003)\end{array}$ \\
\hline Liquidity & & & & $\begin{array}{c}0.045 \\
(0.062)\end{array}$ & $\begin{array}{c}0.028 \\
(0.052)\end{array}$ & $\begin{array}{c}0.139^{* * *} \\
(0.032)\end{array}$ \\
\hline Leverage & & & & $\begin{array}{l}-0.058 \\
(0.067)\end{array}$ & $\begin{array}{l}-0.089 \\
(0.056)\end{array}$ & $\begin{array}{c}0.145^{* * *} \\
(0.031)\end{array}$ \\
\hline Investment & & & & $\begin{array}{c}1.073^{* * *} \\
(0.090)\end{array}$ & $\begin{array}{c}0.878^{* * *} \\
(0.088)\end{array}$ & \\
\hline \multicolumn{7}{|l|}{ Controls: } \\
\hline Private $_{i}$, Credit $_{t-1}$, ExtDep $_{j}$ & Yes & Yes & Yes & Yes & Yes & Yes \\
\hline Firm FE & Yes & Yes & Yes & Yes & Yes & Yes \\
\hline Time FE & Yes & Yes & Yes & Yes & Yes & Yes \\
\hline Observations & 94,371 & 93,282 & 63,417 & 91,853 & 90,800 & 61,281 \\
\hline R-squared & 0.069 & 0.059 & 0.003 & 0.081 & 0.073 & 0.021 \\
\hline \multicolumn{7}{|c|}{$\begin{array}{l}\text { Table presents the estimates of Eq. (4). The dependent variable in columns }(1) \text { and }(4) \text { is the growth } \\
\text { rate of } \mathrm{R} \& \mathrm{D} \text { investment in year } t \text {, in columns }(2) \text { and }(5) \text { is the growth rate of the ratio of } \mathrm{R} \& \mathrm{D} \text { to } \\
\text { sales, while in columns }(3) \text { and }(6) \text { it is the share of } \mathrm{R} \& \mathrm{D} \text { to total investment. Private } e_{i} \text { is a dummy for } \\
\text { private firms. Credit } t_{t-1} \text { is a dummy taking the value one in } 2008-2010 \text { and } 2012-2013 \text {. ExtDep } p_{j} \text { is the } \\
\text { measure of dependence of external finance in industry } j \text {. Total Assets is the log of total assets. Liquidity } \\
\text { is the difference between current assets and current liabilities scaled down by total assets. Leverage is } \\
\text { defined as the ratio of liabilities to total assets. Investment is the log of investment measured as the } \\
\text { gross change in fixed assets. Standard errors are clustered at the country level. * } * * * * * * \text { represents } \\
\text { significance at } 10,5 \text { and } 1 \% \text { level. }\end{array}$} \\
\hline
\end{tabular}

estimations which relate the Private $_{i}$ dummy to a set of firm characteristics in 2007 and 2015, respectively. As expected, private firms tend to be significantly smaller, where size is measured by the log of total assets. They also have significantly lower investment and they tend to be less liquid where Liquidity is defined as the difference between current assets and current liabilities scaled down by total assets. Interestingly, private firms were more leveraged in 2007, but not in 2015. Leverage is defined here as the ratio of liabilities to total assets. We thus perform a similar empirical exercise as in Table 3, while controlling for these systematic differences between private and listed firms. The results are presented in Appendix Table A2 and show consistent estimates for our main interaction term: private firms in industries highly dependent on external finance invest less in innovation in periods of tight credit supply. The regressions include country, industry, time as well as country-industry fixed effects.

In Table 4, we present an alternative empirical exercise where instead of the split sample analysis by industry dependence on external finance, we include a triple interaction term between the Private $_{i}$, Credit $_{t-1}$ and the industry-level measure of external dependence, ExtDep . $_{\text {. }}$ 
The model estimated is as follows:

$$
\begin{aligned}
Y_{i, t}= & \beta_{0}+\beta_{1} \text { Private }_{i} \times \text { Credit }_{t-1} \times \text { ExtDep }_{j}+\beta_{2} \text { Private }_{i}+\beta_{3} \text { Credit }_{t-1}+ \\
& +\beta_{4} \text { ExtDep }_{j}+\theta^{\prime} X_{i, j, t}+\epsilon_{i, t},
\end{aligned}
$$

where, as before, $Y_{i, t}$ is one of the three measures of investment in innovation. We control in these estimations for firm and year fixed effects, as well as the time-varying firm characteristics discussed above. The coefficient of interest is $\beta_{1}$, which captures the differential investment in innovation of private firms during periods of tight credit supply in industries with a higher dependence on external finance. We present the estimates of Eq. (6) in Table 4. Columns (1)-(3) present the baseline model including firm and year fixed effects, while columns (4)-(6) add the other firm-level controls. Again, regardless of the measure of innovation employed, we find consistent estimates: private firms invest disproportionately less in innovation, following periods of tight credit supply and particularly in industries that have a higher dependence on external finance. The analysis in Table 4 also shows that our results are robust to alternative empirical strategies.

\subsection{Accounting for the cross-country variation in credit supply}

The extent of the tightening in credit supply, especially following the Sovereign debt crisis, was different among the sample of European countries considered. For example, the measure of changes in credit standards collected by the ECB shows that $43 \%$ more banks tightened credit supply in Italy in 2012 as compared to those that relaxed them, while the difference between those who tightened and those who relaxed credit standards was only $3 \%$ in the same year in Germany. To account for this heterogeneity in the severity of the credit crunch across countries, we augment the model in Eq. (4) as follows:

$$
\begin{aligned}
Y_{i, t}= & \beta_{0}+\beta_{1} \text { Private }_{i} \times \text { Credit }_{t-1} \times B L S_{c, t}+\beta_{2} \text { Private }_{i}+\beta_{3} \text { Credit }_{t-1}+ \\
& +\beta_{4} B L S_{c, t}+\theta^{\prime} X_{c, i, j, t}+\epsilon_{, i t},
\end{aligned}
$$

where our coefficient of interest is now the triple interaction term between Private $_{i}$, the time dummy Credit $_{t-1}$ and the country level index of credit standards, $B L S_{c, t}$. The latter is a survey-based variable collected by the European Central Bank across a large sample of banks operating in Euro area countries. This measure is computed as the difference between the share of banks that have tightened credit standards and those that have relaxed them. As such, higher values imply that more banks have tightened their credit conditions than eased 
Table 5: Accounting for the cross-country heterogeneity in credit supply

\begin{tabular}{|c|c|c|c|c|c|c|}
\hline \multirow[t]{2}{*}{ Dependent variables: } & \multicolumn{2}{|c|}{$R \& D$} & \multicolumn{2}{|c|}{$\frac{R \& D}{\text { Sales }}$} & \multicolumn{2}{|c|}{$\frac{R \& D}{\text { Investment }}$} \\
\hline & $(1)$ & $(2)$ & $(3)$ & $(4)$ & $(5)$ & $(6)$ \\
\hline \multicolumn{7}{|c|}{ Panel A: Firms in industries with high dependence on external finance } \\
\hline Private $_{i} \times$ Credit $_{t-1} \times B L S_{c, t}$ & $\begin{array}{c}-0.001^{* * *} \\
(0.000)\end{array}$ & $\begin{array}{c}-0.001^{* * *} \\
(0.000)\end{array}$ & $\begin{array}{c}-0.001^{* * *} \\
(0.000)\end{array}$ & $\begin{array}{c}-0.001^{* * *} \\
(0.000)\end{array}$ & $\begin{array}{c}-0.001^{* * *} \\
(0.000)\end{array}$ & $\begin{array}{c}-0.001^{* * *} \\
(0.000)\end{array}$ \\
\hline Observations & 42,955 & 42,955 & 42,637 & 42,637 & 31,404 & 31,404 \\
\hline \multicolumn{7}{|c|}{ Panel B: Firms in industries with low dependence on external finance } \\
\hline Private $_{i} \times$ Credit $_{t-1} \times B L S_{c, t}$ & $\begin{array}{c}-0.001^{*} \\
(0.000)\end{array}$ & $\begin{array}{c}-0.001^{*} \\
(0.000)\end{array}$ & $\begin{array}{c}-0.001 \\
(0.000)\end{array}$ & $\begin{array}{c}-0.001^{*} \\
(0.000)\end{array}$ & $\begin{array}{c}0.001^{*} \\
(0.000)\end{array}$ & $\begin{array}{l}0.001^{*} \\
(0.000)\end{array}$ \\
\hline Observations & 44,043 & 44,043 & 43,837 & 43,837 & 27,790 & 27,790 \\
\hline \multicolumn{7}{|l|}{ Controls: } \\
\hline Private $_{i}$, Credit $_{t-1}$, BLS $_{c, t}$ & Yes & Yes & Yes & Yes & Yes & Yes \\
\hline Country FE & Yes & & Yes & & Yes & \\
\hline Industry FE & Yes & & Yes & & Yes & \\
\hline Time FE & Yes & Yes & Yes & Yes & Yes & Yes \\
\hline Country-industry FE & & Yes & & Yes & & Yes \\
\hline
\end{tabular}

Table presents the estimates of Eq. (6). The dependent variable in columns (1)-(2) is the growth rate of $R \& D$ investment in year $t$, in columns (3)-(4) is the growth rate of the ratio of R\&D to sales, while in column (5)-(6) it is the share of R\&D to total investment. Panel A includes industries with an above the median dependence on external finance, while Panel B those with a below the median dependence. Private $i$ is a dummy for private firms. Credit $t_{t-1}$ is a dummy taking the value one in 2008-2010 and 2012-2013. BLS $S_{c, t}$ is the difference between the share of banks that have tightened their credit standards and the share of those who have loosened them, in country $c$, during year $t$. Standard errors are clustered at the country level. $* / * * / * * *$ represents significance at 10,5 and $1 \%$ level.

them. Recent work shows that this measure is highly informative of the aggregate credit conditions in an economy (see De Bondt et al. 2010, Becker \& Ivashina 2017). The empirical strategy in Eq. (7) allows us to exploit both the time-series, as well as the cross-sectional variation in credit supply across Euro area countries. This approach gives us two sources of identifying variations in our analysis: the time before and after the beginning of the two crises in our model, as well as the cross-sectional variation of the severity of these crises among the sample of countries considered.

The results are presented in Table 5, where we perform the same split sample analysis depending on the industry-level dependence on external finance. Results are consistent across all specifications: private firms invest disproportionately less in R\&D during periods of tight credit supply in particular in countries where the contraction in credit supply was more severe.

\subsection{Alternative measures of financial constraints}

Our identification strategy thus far has been based on the premise that publicly traded firms face similar aggregate demand shocks as unlisted firms, but less financial constraints, as they 
can rely on other sources of financing when bank credit is tight. A concern is that the variation in aggregate demand shocks might still impact some industries more than others, in a way that it leads private firms to systematically be less likely to invest in innovation. Although segmenting our sample by more or less financially dependent industries and using country-by-year and industry-by-year fixed effects does help to address this particular issue, we present additional results where we employ alternative proxies for financial constraints at the firm level. These alternative classifications of firms should further mitigate the concern that private firms systematically face different aggregate demand conditions that can explain their investment behavior.

First, we consider firm size. Farre-Mensa \& Ljungqvist (2016) show that size correlates to the extent of financial constraints, particularly among private firms. Moreover, the relationship between size and investment in R\&D is confounded. In an important work, Klette \& Kortum (2004) show that R\&D intensity or R\&D to sales, is independent of firm size. On the other hand, Seru (2014) finds that smaller firms are more innovative and produce a larger number of patents. In a general equilibrium framework, Akcigit \& Kerr (2017) model the interactions between firm size and two types of investment in R\&D: exploration (product) and exploitation (process) R\&D. In a sample of US firms they show that smaller firms have higher R\&D to sales and that the relative rate of product $R \& D$ is higher in small firms. Larger firms, on the other hand, tend to invest more in process R\&D.

Whether or not small firms invest less in innovation will nonetheless only affect the level and not the trend of $R \& D$ spending. It is thus reasonable to assume that the trend of $R \& D$ investment and its intensity are not systematically related to our measure of firm size. We thus construct a dummy variable called $S_{\text {mall }}$ that takes the value of 1 if a firm is in the $25^{\text {th }}$ percentile of the distribution of firms by total assets in a given industry and 0 if it is in the $75^{\text {th }}$ percentile. We classify firms according to this criteria in 2007 and include them in the treatment or control group based on this definition throughout all other years in the sample. We then repeat the empirical strategy in Eq. (7), where we replace Private $_{i}$ with the $\operatorname{Small}_{i}$ dummy. We perform the same split sample analysis according to the industry level of external finance dependence. We obtain consistent results across all measures of investment in innovation.

In addition to the two proxies of financial constraints employed so far, which are arguably the most exogenous to business conditions, we construct two additional standard balance sheet measures of firms' financial health (see, among others, Fazzari \& Petersen 1993, Manova \& Yu 2016, Giroud \& Mueller 2017). The first measure, called Liquidity captures a firm's 
Table 6: Alternative measures of financial constraints: firm size

\begin{tabular}{|c|c|c|c|c|c|c|}
\hline \multirow[t]{2}{*}{ Dependent variables: } & \multicolumn{2}{|c|}{$R \& D$} & \multicolumn{2}{|c|}{$\frac{R \& D}{S g l o s}$} & \multicolumn{2}{|c|}{ 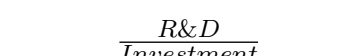 } \\
\hline & $\begin{array}{l}\text { High } \\
(1)\end{array}$ & $\begin{array}{c}\text { Low } \\
(2)\end{array}$ & $\begin{array}{l}\text { High } \\
(3)\end{array}$ & $\begin{array}{c}\text { Low } \\
\text { (4) }\end{array}$ & High $^{1 n}$ & $\begin{array}{c}\text { Lent } \\
\text { Low } \\
(6)\end{array}$ \\
\hline Small $_{i} \times$ Credit $_{t-1} \times B L S_{c, t}$ & $\begin{array}{c}-0.001^{* * *} * \\
(0.000)\end{array}$ & $\begin{array}{c}0.001 \\
(0.000)\end{array}$ & $\begin{array}{c}-0.001^{* * *} \\
(0.000)\end{array}$ & $\begin{array}{l}-0.001 \\
(0.000)\end{array}$ & $\begin{array}{c}-0.001^{* *} \\
(0.000)\end{array}$ & $\begin{array}{c}0.001 \\
(0.000)\end{array}$ \\
\hline Total Assets & $\begin{array}{c}-0.026^{* * *} \\
(0.007)\end{array}$ & $\begin{array}{c}0.017 \\
(0.018)\end{array}$ & $\begin{array}{c}0.040^{* * *} \\
(0.011)\end{array}$ & $\begin{array}{c}0.096^{* * *} \\
(0.020)\end{array}$ & $\begin{array}{c}0.002 \\
(0.009)\end{array}$ & $\begin{array}{c}0.014^{* *} \\
(0.007)\end{array}$ \\
\hline Sales & $\begin{array}{c}0.034^{* * *} \\
(0.008)\end{array}$ & $\begin{array}{l}-0.012 \\
(0.011)\end{array}$ & $\begin{array}{c}-0.052^{* * *} \\
(0.006)\end{array}$ & $\begin{array}{c}-0.113^{* * *} \\
(0.014)\end{array}$ & $\begin{array}{l}-0.011 \\
(0.007)\end{array}$ & $\begin{array}{c}-0.020^{* *} \\
(0.009)\end{array}$ \\
\hline Liquidity & $\begin{array}{l}-0.030 \\
(0.059)\end{array}$ & $\begin{array}{l}-0.001 \\
(0.117)\end{array}$ & $\begin{array}{l}-0.016 \\
(0.063)\end{array}$ & $\begin{array}{c}0.012 \\
(0.110)\end{array}$ & $\begin{array}{l}0.111^{*} \\
(0.065)\end{array}$ & $\begin{array}{c}0.132 \\
(0.123)\end{array}$ \\
\hline Leverage & $\begin{array}{c}-0.127^{* *} \\
(0.055)\end{array}$ & $\begin{array}{l}-0.012 \\
(0.120)\end{array}$ & $\begin{array}{l}-0.060 \\
(0.053)\end{array}$ & $\begin{array}{c}0.040 \\
(0.111)\end{array}$ & $\begin{array}{c}0.129^{* * *} \\
(0.049)\end{array}$ & $\begin{array}{l}0.145 \\
(0.110)\end{array}$ \\
\hline Investment & $\begin{array}{c}1.347^{* * *} \\
(0.085)\end{array}$ & $\begin{array}{c}0.962^{* * * *} \\
(0.034)\end{array}$ & $\begin{array}{c}1.136^{* * *} \\
(0.102)\end{array}$ & $\begin{array}{c}0.750^{* * * *} \\
(0.032)\end{array}$ & & \\
\hline Controls: & & & & & & \\
\hline $\operatorname{Small}_{i}$, Credit $_{t-1}$, BLS $_{c, t}$ & Yes & Yes & Yes & Yes & Yes & Yes \\
\hline Country FE & Yes & Yes & Yes & Yes & Yes & Yes \\
\hline Industry FE & Yes & Yes & Yes & Yes & Yes & Yes \\
\hline Time FE & Yes & Yes & Yes & Yes & Yes & Yes \\
\hline Observations & 11,506 & 10,434 & 11,392 & 10,355 & 7,760 & 6,748 \\
\hline
\end{tabular}

Table presents the estimates of Eq. (7). The dependent variable in columns (1)-(2) is the growth rate of $\mathrm{R} \& \mathrm{D}$ investment in year $t$, in columns (3)-(4) is the growth rate of the ratio of $\mathrm{R} \& \mathrm{D}$ to sales, while in columns (5)-(6) it is the share of R\&D to total investment. Columns (1), (3) and (5) include industries with an above the median dependence on external finance, while columns (2), (4) and (6) those with a below the median dependence. Small $i$ is a dummy that takes the value of 1 if a firm is in the 25th percentile of the distribution of firms by total assets in a given industry and 0 if it is in the 75th percentile. Credit $t_{t-1}$ is a dummy taking the value one in 2008-2010 and 2012-2013. BLS $S_{c, t}$ is the difference between the share of banks that have tightened their credit standards and the share of those who have loosened them, in country $c$, during year $t$. Total Assets is the log of total assets. Liquidity is the difference between current assets and current liabilities scaled down by total assets. Leverage is defined as the ratio of liabilities to total assets. Investment is the log of Investment measured as the gross change in fixed assets. Standard errors are clustered at the country level. */**/*** represents significance at 10,5 and $1 \%$ level.

availability of short-term liquid assets and is computed as the difference between current assets and current liabilities, scaled by total assets. While the second measure, called Leverage is the ratio of current liabilities to current assets. Firms with low liquidity have more financial obligations outstanding in the short run and less freedom in managing cash flows or raising additional external capital. Similarly, firms with high leverage are less apt (or able) to raise additional short- and long-term debt in response to aggregate demand conditions or to fund new investment opportunities. We thus expect firms with high liquidity and low leverage to be financially healthier and less constrained. Since these two measures are more sensitive to credit market frictions, for each firm we compute its leverage and liquidity ratios in 2007 and fix it throughout the sample in order to capture pre-crisis balance sheet vulnerabilities. 
Table 7: Alternative measures of financial constraints: balance sheet vulnerabilities

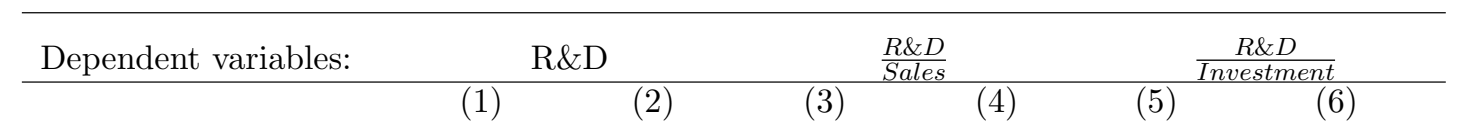

Panel A: Firms in industries with high dependence on external finance

\begin{tabular}{|c|c|c|c|c|c|c|}
\hline Liquidity $_{i} \times$ Credit $_{t}$ & $\begin{array}{c}0.070^{* * *} \\
(0.019)\end{array}$ & & $\begin{array}{c}0.060 * * * \\
(0.017)\end{array}$ & & $\begin{array}{l}-0.020 \\
(0.016)\end{array}$ & \\
\hline Leverage $_{i} \times$ Credit $_{t}$ & & $\begin{array}{l}-0.014 \\
(0.017)\end{array}$ & & $\begin{array}{l}-0.001 \\
(0.018)\end{array}$ & & $\begin{array}{c}0.015^{* * *} \\
(0.006)\end{array}$ \\
\hline Observations & 46,793 & 46,793 & 46,138 & 46,138 & 35,067 & 35,067 \\
\hline \multicolumn{7}{|c|}{ Panel B: Firms in industries with low dependence on external finance } \\
\hline$\overline{\text { Liquidity }}_{i} \times$ Credit $_{t-1}$ & $\begin{array}{c}0.101^{* * *} \\
(0.016)\end{array}$ & & $\begin{array}{c}0.092^{* * *} \\
(0.021)\end{array}$ & & $\begin{array}{l}-0.015 \\
(0.022)\end{array}$ & \\
\hline Leverage $_{i} \times$ Credit $_{t-1}$ & & $\begin{array}{c}-0.031^{* * *} \\
(0.006)\end{array}$ & & $\begin{array}{c}-0.033^{* * *} \\
(0.007)\end{array}$ & & $\begin{array}{c}0.002 \\
(0.008)\end{array}$ \\
\hline Observations & 47,535 & 47,535 & 47,101 & 47,101 & 33,457 & 33,457 \\
\hline \multicolumn{7}{|l|}{ Controls: } \\
\hline Credit $_{t-1}$ & Yes & Yes & Yes & Yes & Yes & Yes \\
\hline Liquidity $_{i}$ & Yes & Yes & Yes & Yes & Yes & Yes \\
\hline Leverage $_{i}$ & Yes & Yes & Yes & Yes & Yes & Yes \\
\hline Time FE & Yes & Yes & Yes & Yes & Yes & Yes \\
\hline Country-industry FE & Yes & Yes & Yes & Yes & Yes & Yes \\
\hline
\end{tabular}

Table presents the estimates of Eq. (4). The dependent variable in columns (1)-(2) is the growth rate of R\&D investment in year $t$, in columns (3)-(4) is the growth rate of the ratio of $\mathrm{R} \& \mathrm{D}$ to sales, while in columns (5)-(6) it is the share of R\&D to total investment. Panel A includes industries with an above the median dependence on external finance, while Panel B those below the median dependence. Liquidity $_{i}$ is the difference between current assets and current liabilities scaled down by total assets in 2007. Leverage $i_{i}$ is defined here as the ratio of liabilities to total assets in 2007. Credit $_{t-1}$ is a dummy taking the value one in 2008-2010 and 2012-2013. Standard errors are clustered at the country level. $* / * * / * * *$ represents significance at 10,5 and $1 \%$ level.

We present the results using these alternative proxies of financial vulnerability at the firm level in Table 7. We find that firms that were more liquid in 2007 are able to invest more in $\mathrm{R} \& \mathrm{D}$ during periods when credit conditions were more tight, as compared to less liquid firms. Moreover, the growth rate of $R \& D$ investment and that of $R \& D$ intensity are both higher in more liquid firms regardless of whether they are in industries more or less dependent on external finance. This is in line with expectations, since more liquid firms are less likely to be dependent on external financing and can smooth $R \& D$ spending as a result. On the other hand, we do not find that these firms have a significantly different composition of investment, as the ratio of $R \& D$ to investment is never statistically significant. The effect of leverage, however, is more ambiguous. We do find that more leveraged firms invest less in innovation, however, surprisingly, this result is only valid in industries with a below the median dependence on external finance (Panel B of Table 7). 


\subsection{R\&D intensive industries and financial constraints}

R\&D investment often faces higher adjustments costs which makes it expensive for firms to adjust the flow of $R \& D$ spending in response to transitory financial shocks. As a result, firms sometime hoard cash in order to smooth their R\&D expenditures (Brown \& Petersen 2011, He \& Wintoki 2016). This should be particularly the case among firms that generally invest a lot in $\mathrm{R} \& \mathrm{D}$, or, in other words, firms with a higher R\&D intensity. We test this hypothesis next.

As our analysis thus far shows that R\&D intensity at the firm level is highly sensitive to financial constraints, we circumvent any endogeneity concerns by employing an industry level measures of R\&D intensity. The OECD provides a classification of industries based on their $R \& D$ intensity, which is measured as the percentage of $R \& D$ in gross value added at the industry level (see Galindo-Rueda \& Verger 2016). The classification of industries is countryspecific and at the 2-digit industry level in the year 2014. We thus perform a split sample analysis, where we estimate the model in Eq. (4) for industries with a below or above the median level of R\&D intensity, where the median is computed for each country in 2014. The results are presented in Table 8 for various proxies of financial constraints at the firm level. Consistent with the idea that firms with a high R\&D intensity might build up cash reserves to smooth $R \& D$ investment, we find that private firms invest disproportionately less in $R \& D$, in particular in industries with low $R \& D$ intensity. The coefficient of the interaction term Private $_{i} \times$ Crisis $_{t-1}$ is negative and statistically significant in industries below the median of R\&D intensity, and not above. This result is also consistent across all measures of innovation spending. The interaction terms employing the other measures of financial constraints are less precisely estimated. The $\operatorname{Small}_{i}$ dummy is only statistically significant in one case, while, consistent with previous results, we find that more liquid firms invest more in $\mathrm{R} \& \mathrm{D}$, but mainly in R\&D intensive industries. The same goes for less leveraged firms.

The evidence presented in this section suggests that even private firms might be able to smooth $R \& D$ investment, if they generally engage a lot in this type of spending. This can be due to the fact that R\&D intensive firms hoard more cash. Brown \& Petersen (2011) and He \& Wintoki (2016), among others, document this tendency of R\&D intensive firms to hoard cash among listed US firms. While hoarding cash is indicative that financial frictions matter for $R \& D$ investment, we test whether our results are sensitive to the inclusion of changes in cash holdings. We thus replicate the baseline model in Eq. (4) including the change in Cash holding in a given year alongside other firm level characteristics. The results are presented in Table A3. As only a significantly smaller sample of firms report data on cash holdings, our estimates 
Table 8: Alternative model: R\&D intensive industries and financial constraints

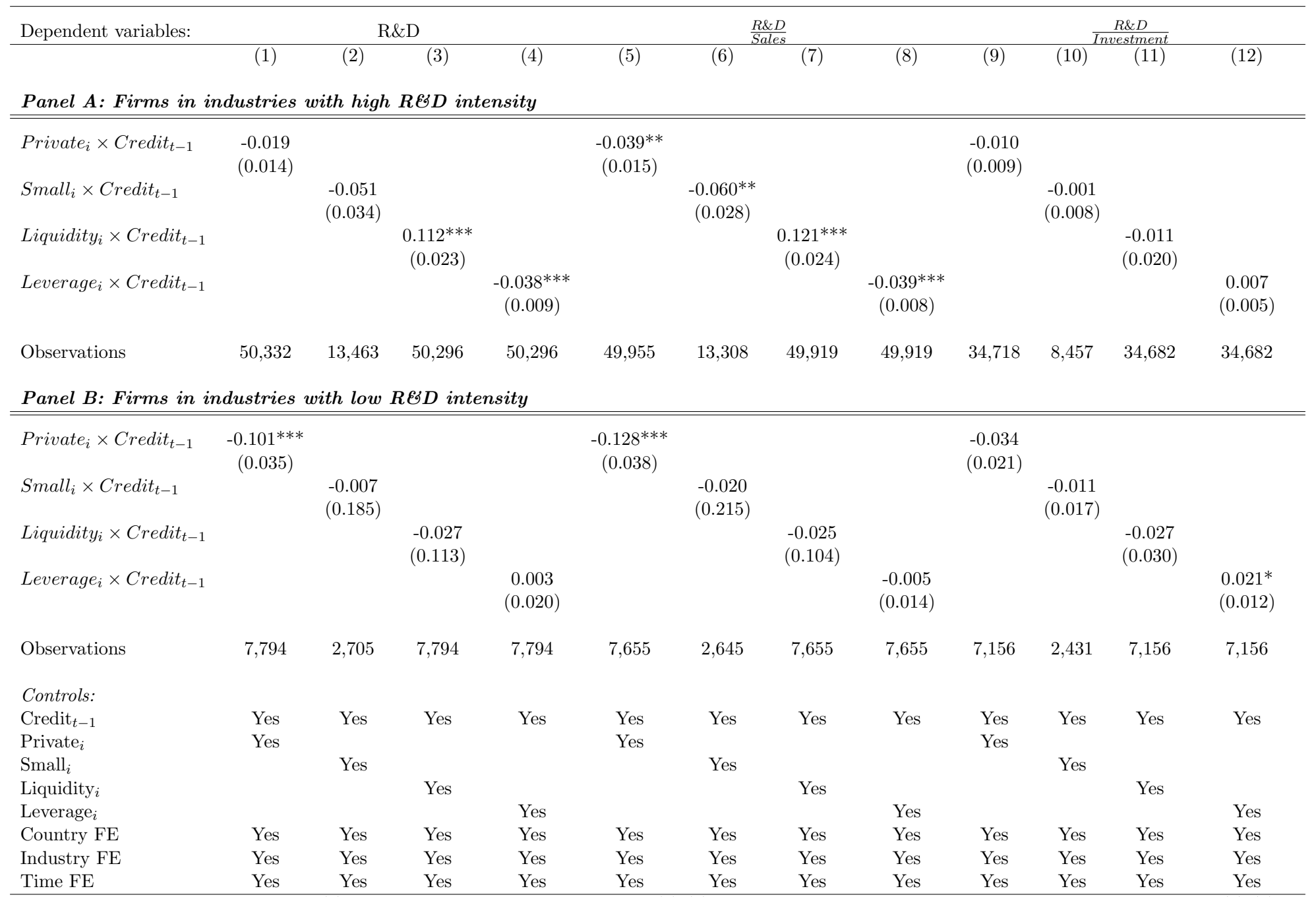

Table presents the estimates of Eq. (4). The dependent variable in columns (1)-(2) is the growth rate of R\&D investment, in year $t$, in columns (3)-(4) is the growth rate of the ratio of $R \& D$ to sales, while in columns (5)-(6) it is the share of $R \& D$ to total investment. Columns (1), (3) and (5) include industries with an above the median dependence on external finance, while columns (2), (4) and (6) those with below the median dependence. Private $e_{i}$ is a dummy for private firms. Credit $t_{t-1}$ is a dummy taking the value one in 2008-2010 and 2012-2013. Small $_{i}$ is a dummy that takes the value of 1 if a firm is in the 25 th percentile of the distribution of firms by total assets in a given industry and 0 if it is in the 75 th percentile. Liquidity is the difference between current assets and current liabilities scaled down by total assets in 2007. Leverage is defined here as the ratio of liabilities to total assets in 2007. Standard errors are clustered at the country level. $* / * * / * * *$ represents significance at 10,5 and $1 \%$ level. 
are less precise, but we still find a significantly lower investment in innovation among private firms during periods of tight credit supply. Moreover, the changes in cash holdings do not seem to have any explanatory power once we account for proxies of financial constraints.

\subsection{Other robustness tests}

In this section we consider a set of additional robustness tests for our main results. First, while we show that private smaller firms, are less likely to engage in spending on innovation when credit supply is low, this does not imply that aggregate investment in innovation is affected, especially if the bulk of R\&D spending is concentrated among listed firms that are less likely to be affected by a contraction in credit supply. To control for observable differences between public and private firms we use a matching procedure that matches our treated and control groups by firm size, measured by either total assets or sales. Firms are matched using propensity scores based on a logit model in 2007 that relates the probability of being assigned to the treated group to firm size. We then employ this propensity score to re-weight treatment and control groups such that the distribution of firm size looks the same in both groups. This is done using the conditional probability of being in the treated group, $\hat{\lambda}$, to compute a weight as the odds ratio $\hat{\lambda} /(1-\hat{\lambda}$ ) (see Nichols 2007). We then re-estimate the model in Eq. (6) using the weighted data based on propensity scores. The results are presented in Tables A5 and $\mathrm{A} 6$ and show consistent estimates.

Second, we perform a series of robustness tests with regards to various variable definitions. We estimate the split sample analysis in Table 3 by classifying industries with a high dependence on external finance as those in the $75^{\text {th }}$ percentile of the distribution of the Rajan \& Zingales (1998) index, while those in the $25^{\text {th }}$ percentile as low dependent. Third, we use different attrition rules in selecting the sample of firms. Our sample contains firms with at least four years of reported $R \& D$ data to avoid that results are driven by the higher coverage of firms towards the end of the sample period. We apply a more stringent attrition rule by limiting the sample to firms that report at least 9 years of $R \& D$ data. This assures us that firms are present in the sample during both crises episodes. Next, we saturate all models presented with two-way fixed effects. Most of the results presented include country-industry fixed effects. We check the robustness of these estimations when including industry-year and country-year fixed effects. Our main results are qualitatively the same in all these alternative specifications, and, for brevity, we do not include them, but they can be obtained from the authors.

Finally, we perform a series of falsification strategies commonly employed in difference-indifference identification strategies. Specifically, we repeat the empirical exercise in Eq. (4) 
by randomly changing the crisis year. Next, we also randomize the treatment and control assignment, by setting the dummy Private $_{i}$ to 1 in a random sample of firms. The results are presented in Appendix Table A4. The coefficient of the interaction term Private $_{i} \times$ Credit $_{t-1}$ is no longer significant in most cases, or significant at $10 \%$ but only in low dependent industries. Overall, these results strengthen our identification strategy and show that the disproportionally lower investment in $\mathrm{R} \& \mathrm{D}$ is specific to firms that are more credit constrained, during periods of tight credit supply and not just an artefact of the data.

\section{Conclusion}

A long standing argument in the finance and innovation literature views a limited role for bank credit in financing investments in innovation such as $R \& D$ spending. This is because these investments generally face more severe informational problems, highly uncertain returns and, most importantly, cannot be easily collateralized. In this paper, we show that bank finance matters for investments in innovation during periods of tight credit supply, such as the ones that followed the 2008-09 Global financial crisis and 2012 Sovereign debt crisis in Europe.

We exploit three sources of exogenous variation in financial conditions in our identification strategy: the time and cross-country variation in credit standards; the cross-firm heterogeneity of financial constraints; and a cross-industry variation in dependence on external finance. Controlling for firms characteristics and a wide array of fixed effects, we show that firms that are more likely credit constrained, in industries more dependent on external finance invest disproportionately less in innovation during periods of tight credit supply. These results are consistent across different measures of spending on innovation, such as the growth rate of $R \& D$ investment, the growth rate of $R \& D$ intensity and the share of $R \& D$ investment in total investment. Moreover, our findings are also robust to various measures of financial constraints at the firm-level including the difference between private and listed firms, small and large, more or less liquid/leveraged firms.

Our results point to a significant disruption in investment in innovation in Europe as a result of the drop in credit supply that followed the distress in its banking sector. Given the importance of R\&D investment in long-run growth, this disproportionally lower investment in innovation can have implications that go beyond the episode of credit market disruption. 


\section{References}

Acharya, V. \& Xu, Z. (2017), 'Financial dependence and innovation: The case of public versus private firms', Journal of Financial Economics 124(2), 223-243.

Aghion, P., Angeletos, G.-M., Banerjee, A. \& Manova, K. (2010), 'Volatility and growth: Credit constraints and the composition of investment', Journal of Monetary Economics $\mathbf{5 7}(3), 246-265$.

Aghion, P., Askenazy, P., Berman, N., Cette, G. \& Eymard, L. (2012), 'Credit constraints and the cyclicality of R\&D investment: Evidence from France', Journal of the European Economic Association 10(5), 1001-1024.

Aghion, P., Banerjee, A. \& Piketty, T. (1999), 'Dualism and macroeconomic volatility', The Quarterly Journal of Economics 114(4), 1359-1397.

Akcigit, U. \& Kerr, W. R. (2017), 'Growth through heterogeneous innovations', Journal of Political Economy .

Anzoategui, D., Comin, D., Gertler, M. \& Martinez, J. (2017), Endogenous technology adoption and R\&D as sources of business cycle persistence, Technical report, NBER.

Balduzzi, P., Brancati, E. \& Schiantarelli, F. (2017), 'Financial markets, banks' cost of funding, and firms' decisions: Lessons from two crises', Journal of Financial Intermediation .

Becker, B. \& Ivashina, V. (2014), 'Cyclicality of credit supply: Firm level evidence', Journal of Monetary Economics 62, 76-93.

Becker, B. \& Ivashina, V. (2017), 'Financial repression in the European sovereign debt crisis', Review of Finance (forthcoming) .

Benfratello, L., Schiantarelli, F. \& Sembenelli, A. (2008), 'Banks and innovation: Microeconometric evidence on italian firms', Journal of Financial Economics 90(2), 197-217.

Bentolila, S., Jansen, M., Jiménez, G. \& Ruano, S. (2015), 'When credit dries up: Job losses in the great recession'.

Bernstein, S. (2015), 'Does going public affect innovation?', The Journal of Finance 70(4), 1365-1403.

Bloom, N. (2007), 'Uncertainty and the dynamics of R\&D', American Economic Review 97(2), 250-255. 
Bofondi, M., Carpinelli, L. \& Sette, E. (2018), 'Credit supply during a sovereign debt crisis', Journal of the European Economic Association 16(3), 696-729.

Brown, J. R., Fazzari, S. M. \& Petersen, B. C. (2009), 'Financing innovation and growth: Cash flow, external equity, and the 1990s R\&D boom', Journal of Finance 64(1), 151-185.

Brown, J. R., Martinsson, G. \& Petersen, B. C. (2012), 'Do financing constraints matter for R\&D?', European Economic Review 56(8), 1512-1529.

Brown, J. R., Martinsson, G. \& Petersen, B. C. (2017), 'Stock markets, credit markets, and technology-led growth', Journal of Financial Intermediation 32, 45-59.

Brown, J. R. \& Petersen, B. C. (2011), 'Cash holdings and R\&D smoothing', Journal of Corporate Finance 17(3), 694-709.

Chava, S., Oettl, A., Subramanian, A. \& Subramanian, K. (2013), 'Banking deregulation and innovation', Journal of Financial Economics 109(3), 759-774.

Chor, D. \& Manova, K. (2012), 'Off the cliff and back? credit conditions and international trade during the global financial crisis', Journal of International Economics 87(1), 117-133.

Cingano, F., Manaresi, F. \& Sette, E. (2016), 'Does credit crunch investment down? new evidence on the real effects of the bank-lending channel', The Review of Financial Studies 29(10), 2737-2773.

Claessens, S. \& Laeven, L. (2003), 'Financial development, property rights, and growth', The Journal of Finance 58(6), 2401-2436.

Cornaggia, J., Mao, Y., Tian, X. \& Wolfe, B. (2015), 'Does banking competition affect innovation?', Journal of Financial Economics 115(1), 189-209.

De Bondt, G., Maddaloni, A., Peydró, J.-L. \& Scopel, S. (2010), 'The euro area bank lending survey matters: Empirical evidence for credit and output growth', European Central Bank WP 1160 .

Duval, R., Hong, G.-H. \& Timmer, Y. (2019), 'Financial frictions and the great productivity slowdown', Review of Financial Studies (forthcoming) .

Farre-Mensa, J. \& Ljungqvist, A. (2016), 'Do measures of financial constraints measure financial constraints?', Review of Financial Studies 29(2), 271-308.

Fazzari, S. M. \& Petersen, B. C. (1993), 'Working capital and fixed investment: new evidence on financing constraints', RAND Journal of Economics pp. 328-342. 
Feldman, N. E., Kawano, L., Patel, E., Rao, N., Stevens, M., Edgerton, J. et al. (2018), The long and short of it: Do public and private firms invest differently?, Technical report, Board of Governors of the Federal Reserve System (US).

Ferrando, A., Popov, A. \& Udell, G. F. (2017), 'Sovereign stress and smes' access to finance: Evidence from the ecb's SAFE survey', Journal of Banking $\mathcal{E}$ Finance 81, 65-80.

Galindo-Rueda, F. \& Verger, F. (2016), 'OECD taxonomy of economic activities based on R\&D intensity'.

URL: https://www.oecd-ilibrary.org/content/paper/5jlv73sqqp8r-en

Gao, H., Harford, J. \& Li, K. (2013), 'Determinants of corporate cash policy: Insights from private firms', Journal of Financial Economics 109(3), 623-639.

Garicano, L. \& Steinwender, C. (2016), 'Survive another day: does uncertain financing affect the composition of investment?', The Review of Economics and Statistics 98(5), 913-924.

Giroud, X. \& Mueller, H. M. (2017), 'Firm leverage, consumer demand, and employment losses during the great recession', Quarterly Journal of Economics 132(1), 271-316.

Hall, B. H., Mairesse, J. \& Mohnen, P. (2010), 'Measuring the returns to R\&D', Handbook of the Economics of Innovation 2, 1033-1082.

Haltiwanger, J., Jarmin, R. S. \& Miranda, J. (2013), 'Who creates jobs? small versus large versus young', Review of Economics and Statistics 95(2), 347-361.

He, Z. \& Wintoki, M. B. (2016), 'The cost of innovation: R\&D and high cash holdings in us firms', Journal of Corporate Finance 41, 280-303.

Iyer, R., Peydro, J.-L., da Rocha-Lopes, S. \& Schoar, A. (2014), 'Interbank liquidity crunch and the firm credit crunch: Evidence from the 2007-2009 crisis', Review of Financial Studies $\mathbf{2 7}(1), 347-372$.

Kalemli-Ozcan, S., Sorensen, B., Villegas-Sanchez, C., Volosovych, V. \& Yesiltas, S. (2015), How to construct nationally representative firm level data from the orbis global database, Working Paper 21558, National Bureau of Economic Research.

Kaplan, S. N. \& Zingales, L. (1997), 'Do investment-cash flow sensitivities provide useful measures of financing constraints?', Quarterly Journal of Economics 112(1), 169-215.

Kerr, W. R. \& Nanda, R. (2015), 'Financing innovation', Annual Review of Financial Economics 7, 445-462. 
Klette, T. J. \& Kortum, S. (2004), 'Innovating firms and aggregate innovation', Journal of Political Economy 112(5), 986-1018.

Kroszner, R. S., Laeven, L. \& Klingebiel, D. (2007), 'Banking crises, financial dependence, and growth', Journal of Financial Economics 84(1), 187-228.

Manova, K. \& Yu, Z. (2016), 'How firms export: Processing vs. ordinary trade with financial frictions', Journal of International Economics 100, 120-137.

Nanda, R. \& Nicholas, T. (2014), 'Did bank distress stifle innovation during the great depression?', Journal of Financial Economics 114(2), 273-292.

Nichols, A. (2007), 'Causal inference with observational data', Stata Journal 7(4), 507.

Peia, O. (2017), 'Banking crises and investment in innovation', UCD Centre for Economic Research Working Paper Series WP17/27. Available at SSRN: http://ssrn.com/abstract=2761057 .

Rajan, R. G. \& Zingales, L. (1998), 'Financial dependence and growth', American Economic Review 88(3), 559-86.

Ranciere, R., Tornell, A. \& Westermann, F. (2008), 'Systemic crises and growth', The Quarterly Journal of Economics 123(1), 359-406.

Reinhart, C. M. \& Rogoff, K. S. (2014), 'Recovery from financial crises: Evidence from 100 episodes', American Economic Review 104(5), 50-55.

Ridder, M. d. (2017), 'Investment in productivity and the long-run effect of financial crisis on output', CESifo Working Paper Series No. 6243. Available at SSRN: https://ssrn.com/abstract=2906232 .

Robb, A. M. \& Robinson, D. T. (2014), 'The capital structure decisions of new firms', The Review of Financial Studies 27(1), 153-179.

Saunders, A. \& Steffen, S. (2011), 'The costs of being private: Evidence from the loan market', Review of Financial Studies 24(12), 4091-4122.

Schmitz, T. (2017), 'Endogenous growth, firm heterogeneity and the long-run impact of financial crises', mimeo Bocconi University .

Scopel, S., Hempell, H. S., Köhler-Ulbrich, P. et al. (2016), The euro area bank lending survey, Technical report, European Central Bank. 
Seru, A. (2014), 'Firm boundaries matter: Evidence from conglomerates and r\&d activity', Journal of Financial Economics 111(2), 381-405.

Whited, T. M. \& Wu, G. (2006), 'Financial constraints risk', The Review of Financial Studies 19(2), 531-559. 


\section{A Appendix}

\section{A Variables}

\begin{tabular}{|c|c|c|}
\hline Variable & Definition & Source \\
\hline $\mathrm{R} \& \mathrm{D}$ & $\begin{array}{l}\text { Growth rate of } \mathrm{R} \& D \text { spending at time } t \text {, calculated as } \\
g_{i, t}^{R \& D}=\frac{R \& D_{i, t}-R \& D_{i, t-1}}{\frac{1}{2}\left(R \& D_{i, t}+R \& D_{i, t-1}\right)}\end{array}$ & Bureau van Dijk \\
\hline$\frac{R \& D}{\text { Sales }}$ & Ratio of R\&D spending to sales. & Bureau van Dijk \\
\hline$\frac{R \& D}{\text { Investment }}$ & $\begin{array}{l}\text { Ratio of } R \& D \text { to total investment, where total invest- } \\
\text { ment is computed as the sum of } R \& D \text { spending to fixed } \\
\text { investment. }\end{array}$ & Bureau van Dijk \\
\hline Investment & $\max \left\{\right.$ Fixed Assets $_{t^{-}}$Fixed Assets $t_{-1}+$ Depreciation $\left._{t}, 0\right\}$ & Bureau van Dijk \\
\hline Private & $u m m y=1$ if firm is private. & Bureau van Dijk \\
\hline Credit & $\begin{array}{l}\text { Dummy }=1 \text { in year } 2008-2010 \text { and } 2012-2013 \text { for all coun- } \\
\text { tries. UK, Denmark and Sweden have a value of zero in } \\
2012-2013 \text {. }\end{array}$ & Bureau van Dijk \\
\hline Small & $\begin{array}{l}\text { Dummy }=1 \text { if a firm is in the } 25 \text { th percentile of the total } \\
\text { assets distribution in an industry. }\end{array}$ & Bureau van Dijk \\
\hline ExtDep & $\begin{array}{l}\text { An industry-level measure of external dependence pro- } \\
\text { posed by Rajan \& Zingales (1998). }\end{array}$ & Peia (2017) \\
\hline BLS & $\begin{array}{l}\text { Index based on a survey of banks conducted by the Euro- } \\
\text { pean Central Bank that shows the difference between the } \\
\text { share of banks reporting tightening of credit standards } \\
\text { and the share reporting easing. }\end{array}$ & ECB Statistics \\
\hline Liquidity & $\begin{array}{l}\text { Difference between current assets and current liabilities } \\
\text { divided by total assets. }\end{array}$ & Bureau van Dijk \\
\hline Leverage & Ratio of liabilities to total assets. & Bureau van Dijk \\
\hline $\begin{array}{l}\text { Industry R\&D } \\
\text { Intensity }\end{array}$ & $\begin{array}{l}\text { Dummy }=1 \text { if an industry in a given country is above the } \\
\text { median level of R\&D intensity. }\end{array}$ & OECD \\
\hline
\end{tabular}


Table A1: Baseline results: including country-by-year and industry-by-year fixed effects

\begin{tabular}{|c|c|c|c|c|c|c|}
\hline \multirow[t]{2}{*}{ Dependent variables: } & \multicolumn{2}{|c|}{$\mathrm{R} \& \mathrm{D}$} & \multicolumn{2}{|c|}{$\frac{R \& D}{\text { Sales }}$} & \multicolumn{2}{|c|}{$\frac{R \& D}{\text { Investment }}$} \\
\hline & (1) & $(2)$ & (3) & (4) & (5) & (6) \\
\hline \multicolumn{7}{|c|}{ Panel A: Firms in industries with high dependence on external finance } \\
\hline Private $_{i} \times$ Credit $_{t-1}$ & $\begin{array}{c}-0.030 \\
(0.030)\end{array}$ & $\begin{array}{c}-0.094^{* * *} \\
(0.023)\end{array}$ & $\begin{array}{c}-0.070^{* *} \\
(0.028)\end{array}$ & $\begin{array}{c}-0.097 * * * \\
(0.021)\end{array}$ & $\begin{array}{c}-0.027^{*} \\
(0.014)\end{array}$ & $\begin{array}{c}-0.019 * * \\
(0.008)\end{array}$ \\
\hline Observations & 46,822 & 46,822 & 46,167 & 46,167 & 35,096 & 35,096 \\
\hline \multicolumn{7}{|c|}{ Panel B: Firms in industries with low dependence on external finance } \\
\hline Private $_{i} \times$ Credit $_{t-1}$ & $\begin{array}{c}-0.055^{*} \\
(0.032)\end{array}$ & $\begin{array}{c}-0.072 \\
(0.048)\end{array}$ & $\begin{array}{c}-0.057 \\
(0.044)\end{array}$ & $\begin{array}{c}-0.054 \\
(0.048)\end{array}$ & $\begin{array}{l}-0.005 \\
(0.013)\end{array}$ & $\begin{array}{c}0.008 \\
(0.009)\end{array}$ \\
\hline Observations & 47,549 & 47,549 & 47,115 & 47,115 & 33,471 & 33,471 \\
\hline \multicolumn{7}{|l|}{ Controls: } \\
\hline Private $_{i}$ & Yes & Yes & Yes & Yes & Yes & Yes \\
\hline Credit $_{t-1}$ & Yes & Yes & Yes & Yes & Yes & Yes \\
\hline Country FE & Yes & & Yes & & Yes & \\
\hline Country-time FE & & Yes & & Yes & & Yes \\
\hline Industry FE & & Yes & & Yes & & Yes \\
\hline Industry-time FE & Yes & & Yes & & Yes & \\
\hline
\end{tabular}

Table presents the estimates of Eq. 4. The dependent variable in columns (1)-(2) is the growth rate of $\mathrm{R} \& \mathrm{D}$ investment, in year $t+1$, in columns (3)-(4) is the growth rate of the ration of $\mathrm{R} \& \mathrm{D}$ to sales, while in columns (5)-(6) it is the share of $\mathrm{R} \& \mathrm{D}$ to total investment. Panel A includes industries with an above the median dependence on external finance, while Panel B those with a below the median dependence. Private $i$ is a dummy for private firms. Credit $_{t-1}$ is a dummy taking the value one in 2008-2010 and 2012-2013. Robust standard errors are presented. $* / * * / * * *$ represents significance at 10,5 and $1 \%$ level. 
Table A2: Controlling for firm characteristics

\begin{tabular}{|c|c|c|c|c|c|c|}
\hline \multirow[t]{2}{*}{ Dependent variables: } & \multicolumn{2}{|c|}{$\mathrm{R} \& \mathrm{D}$} & \multicolumn{2}{|c|}{$\frac{R \& D}{\text { Sales }}$} & \multicolumn{2}{|c|}{$\frac{R \& D}{\text { Investment }}$} \\
\hline & $\begin{array}{c}\text { High } \\
(1)\end{array}$ & $\begin{array}{c}\text { Low } \\
(2)\end{array}$ & $\begin{array}{c}\text { High } \\
(3)\end{array}$ & $\begin{array}{l}\text { Low } \\
(4)\end{array}$ & $\begin{array}{l}\text { High } \\
(5)\end{array}$ & $\begin{array}{c}\text { Low } \\
(6)\end{array}$ \\
\hline Private $_{i} \times$ Credit $_{t-1}$ & $\begin{array}{c}-0.071^{* * *} \\
(0.026)\end{array}$ & $\begin{array}{l}-0.024 \\
(0.022)\end{array}$ & $\begin{array}{c}-0.087^{* * *} \\
(0.031)\end{array}$ & $\begin{array}{l}-0.013 \\
(0.019)\end{array}$ & $\begin{array}{c}-0.023^{* *} \\
(0.009)\end{array}$ & $\begin{array}{c}-0.001 \\
(0.009)\end{array}$ \\
\hline Total Assets & $\begin{array}{l}-0.017 \\
(0.015)\end{array}$ & $\begin{array}{c}0.005 \\
(0.012)\end{array}$ & $\begin{array}{c}0.038^{* * *} \\
(0.007)\end{array}$ & $\begin{array}{c}0.075^{* * * *} \\
(0.022)\end{array}$ & $\begin{array}{l}-0.011 \\
(0.007)\end{array}$ & $\begin{array}{c}0.001 \\
(0.006)\end{array}$ \\
\hline Sales & $\begin{array}{l}0.031^{*} \\
(0.019)\end{array}$ & $\begin{array}{c}0.009^{* *} \\
(0.004)\end{array}$ & $\begin{array}{c}-0.034^{* * *} \\
(0.007)\end{array}$ & $\begin{array}{c}-0.071^{* * *} \\
(0.011)\end{array}$ & $\begin{array}{l}-0.010 \\
(0.007)\end{array}$ & $\begin{array}{c}-0.020^{* * * *} \\
(0.006)\end{array}$ \\
\hline Liquidity & $\begin{array}{l}-0.026 \\
(0.024)\end{array}$ & $\begin{array}{c}0.044 \\
(0.055)\end{array}$ & $\begin{array}{l}-0.016 \\
(0.033)\end{array}$ & $\begin{array}{c}0.038 \\
(0.065)\end{array}$ & $\begin{array}{l}0.120^{*} \\
(0.063)\end{array}$ & $\begin{array}{c}0.140 \\
(0.115)\end{array}$ \\
\hline Leverage & $\begin{array}{c}-0.084^{* * *} \\
(0.023)\end{array}$ & $\begin{array}{l}-0.019 \\
(0.049)\end{array}$ & $\begin{array}{c}-0.051^{*} \\
(0.031)\end{array}$ & $\begin{array}{l}-0.006 \\
(0.056)\end{array}$ & $\begin{array}{c}0.131^{* * *} \\
(0.041)\end{array}$ & $\begin{array}{c}0.155 \\
(0.096)\end{array}$ \\
\hline Investment & $\begin{array}{c}1.351^{* * *} \\
(0.149)\end{array}$ & $\begin{array}{c}1.424^{* * *} \\
(0.099)\end{array}$ & $\begin{array}{c}1.062^{* * *} \\
(0.160)\end{array}$ & $\begin{array}{c}1.118^{* * *} \\
(0.115)\end{array}$ & & \\
\hline Controls: & & & & & & \\
\hline Provate $_{i}$, Credit $_{t-1}$ & Yes & Yes & Yes & Yes & Yes & Yes \\
\hline Country FE & Yes & Yes & Yes & Yes & Yes & Yes \\
\hline Industry FE & Yes & Yes & Yes & Yes & Yes & Yes \\
\hline Country-industry FE & Yes & Yes & Yes & Yes & Yes & Yes \\
\hline Time FE & Yes & Yes & Yes & Yes & Yes & Yes \\
\hline Observations & 45,465 & 46,388 & 44,837 & 45,963 & 33,886 & 32,395 \\
\hline
\end{tabular}

Table presents the estimates of Eq. (4). The dependent variable in columns (1)-(2) is the growth rate of $R \& D$ investment, in year $t$, in columns (3)-(4) is the growth rate of the ratio of R\&D to sales, while in columns (5)-(6) it is the share of R\&D to total investment. Columns (1), (3) and (5) include industries with an above the medium dependence on external finance, while columns (2), (4) and (6) with a below the medium. Private $i$ is a dummy for private firms. Credit t-1 is a dummy taking the value one in 2008-2010 and 2012-2013. Total Assets is the log of total assets. Liquidity is the difference between current assets and current liabilities scaled down by total assets. Leverage is defined as the ratio of liabilities to total assets. Investment is the log of investment measured as the gross change in fixed assets. Standard errors are clustered at the country level. $* / * * / * *$ represents significance at 10,5 and $1 \%$ level. 
Table A3: Controlling for firm characteristics (including $\Delta$ Cash)

\begin{tabular}{|c|c|c|c|c|c|c|}
\hline \multirow[t]{2}{*}{ Dependent variables: } & \multicolumn{2}{|c|}{$\mathrm{R} \& \mathrm{D}$} & \multicolumn{2}{|c|}{$\frac{R \& D}{\text { Sales }}$} & \multicolumn{2}{|c|}{$\frac{R \& D}{\text { Investment }}$} \\
\hline & $\begin{array}{l}\text { High } \\
(1)\end{array}$ & $\begin{array}{c}\text { Low } \\
(2)\end{array}$ & High & $\begin{array}{c}\text { Low } \\
\text { (4) }\end{array}$ & $\begin{array}{l}\text { High } \\
(5)\end{array}$ & $\begin{array}{c}\text { Lont } \\
\text { (6) }\end{array}$ \\
\hline Private $_{i} \times$ Credit $_{t-1}$ & $\begin{array}{c}-0.035^{*} \\
(0.020)\end{array}$ & $\begin{array}{l}-0.010 \\
(0.021)\end{array}$ & $\begin{array}{c}-0.043^{*} \\
(0.024)\end{array}$ & $\begin{array}{l}-0.008 \\
(0.018)\end{array}$ & $\begin{array}{c}-0.027^{* * * *} \\
(0.009)\end{array}$ & $\begin{array}{c}-0.009 \\
(0.009)\end{array}$ \\
\hline Total Assets & $\begin{array}{c}-0.031^{* * *} \\
(0.006)\end{array}$ & $\begin{array}{c}0.016 \\
(0.015)\end{array}$ & $\begin{array}{c}0.033^{* * *} \\
(0.005)\end{array}$ & $\begin{array}{c}0.100^{* * *} \\
(0.015)\end{array}$ & $\begin{array}{c}-0.022^{* *} \\
(0.008)\end{array}$ & $\begin{array}{l}-0.006 \\
(0.004)\end{array}$ \\
\hline Sales & $\begin{array}{c}0.048^{* * *} \\
(0.010)\end{array}$ & $\begin{array}{l}0.012^{*} \\
(0.007)\end{array}$ & $\begin{array}{c}-0.029^{* * *} * \\
(0.004)\end{array}$ & $\begin{array}{c}-0.083^{* * *} \\
(0.007)\end{array}$ & $\begin{array}{l}-0.001 \\
(0.004)\end{array}$ & $\begin{array}{c}-0.014^{* * *} \\
(0.005)\end{array}$ \\
\hline Liquidity & $\begin{array}{c}0.003 \\
(0.031)\end{array}$ & $\begin{array}{c}0.100^{* * *} \\
(0.022)\end{array}$ & $\begin{array}{c}0.023 \\
(0.021)\end{array}$ & $\begin{array}{c}0.105^{* * *} \\
(0.027)\end{array}$ & $\begin{array}{l}0.098^{*} \\
(0.055)\end{array}$ & $\begin{array}{c}0.111 \\
(0.107)\end{array}$ \\
\hline Leverage & $\begin{array}{c}-0.057^{* *} \\
(0.026)\end{array}$ & $\begin{array}{c}0.030 \\
(0.020)\end{array}$ & $\begin{array}{l}-0.013 \\
(0.021)\end{array}$ & $\begin{array}{c}0.052^{* *} \\
(0.023)\end{array}$ & $\begin{array}{c}0.109^{* * *} \\
(0.035)\end{array}$ & $\begin{array}{c}0.129 \\
(0.089)\end{array}$ \\
\hline$\Delta$ Cash & $\begin{array}{c}0.001 \\
(0.000)\end{array}$ & $\begin{array}{l}-0.001 \\
(0.000)\end{array}$ & $\begin{array}{c}0.001 \\
(0.000)\end{array}$ & $\begin{array}{c}-0.001 \\
(0.000)\end{array}$ & $\begin{array}{l}-0.001 \\
(0.000)\end{array}$ & $\begin{array}{c}0.001 \\
(0.000)\end{array}$ \\
\hline Investment & $\begin{array}{c}1.244^{* * *} \\
(0.251)\end{array}$ & $\begin{array}{c}1.325^{* * *} \\
(0.128)\end{array}$ & $\begin{array}{c}0.988^{* * *} \\
(0.310)\end{array}$ & $\begin{array}{c}1.038^{* * *} \\
(0.169)\end{array}$ & & \\
\hline Controls: & & & & & & \\
\hline Provate $_{i}$, Credit $_{t-1}$ & Yes & Yes & Yes & Yes & Yes & Yes \\
\hline Country FE & Yes & Yes & Yes & Yes & Yes & Yes \\
\hline Industry FE & Yes & Yes & Yes & Yes & Yes & Yes \\
\hline Country-industry FE & Yes & Yes & Yes & Yes & Yes & Yes \\
\hline Time FE & Yes & Yes & Yes & Yes & Yes & Yes \\
\hline Observations & 26,688 & 33,249 & 26,138 & 32,876 & 15,528 & 19,584 \\
\hline
\end{tabular}

Table presents the estimates of Eq. (4). The dependent variable in columns (1)-(2) is the growth rate of $\mathrm{R} \& \mathrm{D}$ investment, in year $t$, in columns (3)-(4) is the growth rate of the ratio of R\&D to sales, while in columns (5)-(6) it is the share of R\&D to total investment. Columns (1), (3) and (5) include industries with an above the median dependence on external finance, while columns (2), (4) and (6) those with below the median dependence. Private $i$ is a dummy for private firms. Credit $t_{-1}$ is a dummy taking the value one in 2008-2010 and 2012-2013. Total Assets is the log of total assets. Liquidity is the difference between current assets and current liabilities scaled down by total assets. Leverage is defined as the ratio of liabilities to total assets. $\Delta$ Cash is the change in cash holdings between year $t$ and $t-1$. Investment is the log of investment measured as the gross change in Fixed Assets. Standard errors are clustered at the country level. ${ }^{*} / * / * * *$ represents significance at 10,5 and $1 \%$ level. 
Table A4: Falsification strategies

\begin{tabular}{|c|c|c|c|c|c|c|}
\hline \multirow[t]{2}{*}{ Dependent variable } & \multicolumn{2}{|c|}{ R\&D } & \multicolumn{2}{|c|}{$\frac{R \& D}{\text { Sales }}$} & \multicolumn{2}{|c|}{$\frac{R \& D}{\text { Investment }}$} \\
\hline & $\begin{array}{l}\text { High } \\
(1)\end{array}$ & $\begin{array}{c}\text { Low } \\
(2)\end{array}$ & $\begin{array}{c}\text { High } \\
(3)\end{array}$ & $\begin{array}{l}\text { Low } \\
(4)\end{array}$ & $\begin{array}{l}\text { High } \\
(5)\end{array}$ & $\begin{array}{l}\text { Low } \\
(6)\end{array}$ \\
\hline \multicolumn{7}{|c|}{ Panel A: Randomised crisis dates } \\
\hline Private $_{i} \times$ Credit $_{t-1}$ & $\begin{array}{c}0.034 \\
(0.042)\end{array}$ & $\begin{array}{c}0.028 \\
(0.039)\end{array}$ & $\begin{array}{c}0.054 \\
(0.055)\end{array}$ & $\begin{array}{l}-0.014 \\
(0.045)\end{array}$ & $\begin{array}{c}0.001 \\
(0.010)\end{array}$ & $\begin{array}{c}-0.057^{* * *} \\
(0.011)\end{array}$ \\
\hline Other Controls: & $\begin{array}{l}\text { Private, } \\
\text { industry }\end{array}$ & $\begin{array}{l}\text { Credit, } \\
\text { fixed effe }\end{array}$ & $\begin{array}{l}\text { Country, } \\
\text { cts, firm }\end{array}$ & $\begin{array}{l}\text { industry } \\
\text { evel cont }\end{array}$ & $\begin{array}{l}\text { time, } \\
\text { ols }\end{array}$ & untry- \\
\hline Observations & 45,465 & 46,388 & 44,837 & 45,963 & 33,886 & 32,395 \\
\hline
\end{tabular}

Panel B: Randomised private firms

\begin{tabular}{lcccccc}
\hline Private $_{i} \times$ Crisis $_{t-1}$ & -0.003 & $-0.057^{*}$ & -0.009 & $-0.064^{*}$ & 0.011 & $-0.017^{* * *}$ \\
& $(0.047)$ & $(0.032)$ & $(0.031)$ & $(0.036)$ & $(0.018)$ & $(0.005)$ \\
& & & & & \\
Other Controls: & $\begin{array}{l}\text { Private, Credit, Country, industry, time, country- } \\
\text { industry }\end{array}$ & fixed effects, firm level controls
\end{tabular}

\begin{abstract}
$\begin{array}{lllllll}\text { Observations } & 45,465 & 46,388 & 44,837 & 45,963 & 33,886 & 32,395\end{array}$
Table presents the estimates of Eq. 4. The dependent variable in columns (1)-(2) is the growth rate of $R \& D$ investment, in year $t$, in columns (3)-(4) is the growth rate of the ratio of $R \& D$ to sales, while in columns (5)-(6) it is the share of $R \& D$ to total investment. Columns (1), (3) and (5) include industries with an above the median dependence on external finance, while columns (2), (4) and (6) those with a below the median dependence. Panel A includes randomised crisis dates dummies. Panel B includes randomised private firms dummies. Standard errors are clustered at the country level. $* / * * / * *$ represents significance at 10,5 and $1 \%$ level.
\end{abstract}


Table A5: Propensity score matching (Total Assets)

\begin{tabular}{|c|c|c|c|c|c|c|}
\hline \multirow[t]{2}{*}{ Dependent variable } & \multicolumn{2}{|c|}{$R \& D$} & \multicolumn{2}{|c|}{$\frac{R \& D}{\text { Sales }}$} & \multicolumn{2}{|c|}{$\frac{R \& D}{\text { Investment }}$} \\
\hline & (1) & (2) & (3) & (4) & (5) & (6) \\
\hline Private $_{i} \times$ Credit $_{t-1} \times$ ExtDep $_{j}$ & $\begin{array}{c}-0.022^{* * *} \\
(0.004)\end{array}$ & $\begin{array}{c}-0.027^{* * *} \\
(0.002)\end{array}$ & $\begin{array}{c}-0.019^{* * *} \\
(0.004)\end{array}$ & $\begin{array}{c}-0.026^{* * *} \\
(0.002)\end{array}$ & $\begin{array}{l}-0.006 \\
(0.004)\end{array}$ & $\begin{array}{l}-0.005 \\
(0.004)\end{array}$ \\
\hline Other Controls: & \multicolumn{6}{|c|}{$\begin{array}{l}\text { Private, Credit, Country, industry, time, country-industry fixed } \\
\text { effects, firm level controls }\end{array}$} \\
\hline Observations & 91,609 & 91,609 & 90,566 & 90,566 & 66,040 & 66,040 \\
\hline R-squared & 0.084 & 0.094 & 0.075 & 0.085 & 0.019 & 0.043 \\
\hline \multicolumn{7}{|c|}{$\begin{array}{l}\text { Table presents the estimates of Eq. (4). The dependent variable in columns }(1) \text { and }(4) \text { is the growth } \\
\text { rate of R\&D investment in year } t \text {, in columns }(2) \text { and }(5) \text { is the growth rate of the ratio of R\&D to } \\
\text { sales, while in columns (3) and (6) it is the share of R\&D to total investment. Private } e_{i} \text { is a dummy } \\
\text { for private firms. Creditt-1 is a dummy taking the value one in } 2008-2010 \text { and } 2012-2013 \text {. Firm level } \\
\text { controls include: Total Assets, Liquidity, Leverage and Investment. Standard errors are clustered at } \\
\text { the country level. } * / * * / * * * \text { represents significance at } 10,5 \text { and } 1 \% \text { level. }\end{array}$} \\
\hline
\end{tabular}

Table A6: Propensity score matching (Sales)

\begin{tabular}{lcccccc}
\hline \multirow{2}{*}{ Dependent variable } & \multicolumn{2}{c}{ R\&D } & \multicolumn{2}{c}{$\frac{R \& D}{\text { Sales }}$} & \multicolumn{2}{c}{$\frac{R \& D}{{ }^{\frac{R}{\text { Investment }}}}$} \\
& $(1)$ & $(2)$ & $(3)$ & $(4)$ & $(5)$ & $(6)$ \\
\hline Private $_{i} \times$ Credit $_{t-1} \times$ ExtDep $_{j}$ & $-0.021^{* * *}$ & $-0.026^{* * *}$ & $-0.019^{* * *}$ & $-0.025^{* * *}$ & -0.006 & -0.005 \\
& $(0.004)$ & $(0.001)$ & $(0.005)$ & $(0.002)$ & $(0.003)$ & $(0.003)$
\end{tabular}

Other Controls:

Private, Credit, Country, industry, time, country-industry fixed effects, firm level controls

\begin{tabular}{lcccccc} 
Observations & 91,676 & 91,676 & 90,630 & 90,630 & 66,104 & 66,104 \\
R-squared & 0.084 & 0.094 & 0.075 & 0.085 & 0.019 & 0.042 \\
\hline
\end{tabular}

Table presents the estimates of Eq. (4). The dependent variable in columns (1) and (4) is the growth rate of $\mathrm{R} \& \mathrm{D}$ investment in year $t$, in columns (2) and (5) is the growth rate of the ratio of $\mathrm{R} \& \mathrm{D}$ to sales, while in columns (3) and (6) it is the share of R\&D to total investment. Private $i$ is a dummy for private firms. Credit $t_{-1}$ is a dummy taking the value one in 2008-2010 and 2012-2013. Firm level controls include: Total Assets, Liquidity, Leverage and Investment. Standard errors are clustered at the country level. $* / * * / * *$ represents significance at 10,5 and $1 \%$ level. 
Table A7: Industry-level measure of dependence on external finance

NACE Description

ExtDep

Rev.2

\begin{tabular}{|c|c|c|}
\hline 10 & Manufacture of food products & 0.02 \\
\hline 11 & Manufacture of beverages & -0.04 \\
\hline 12 & Manufacture of tobacco products & -1.49 \\
\hline 13 & Manufacture of textiles & 0.10 \\
\hline 14 & Manufacture of wearing apparel & 0.17 \\
\hline 15 & Manufacture of leather and related products & -0.02 \\
\hline 16 & $\begin{array}{l}\text { Manufacture of wood and of products of wood and cork, except furniture; man- } \\
\text { ufacture of articles of straw and plaiting materials }\end{array}$ & 0.01 \\
\hline 17 & Manufacture of paper and paper products & 0.02 \\
\hline 18 & Printing and reproduction of recorded media & 0.19 \\
\hline 20 & Manufacture of chemicals and chemical products & 0.15 \\
\hline 21 & Manufacture of basic pharmaceutical products and pharmaceutical preparations & 4.88 \\
\hline 22 & Manufacture of rubber and plastics products & 0.18 \\
\hline 23 & Manufacture of other non-metallic mineral products & 0.06 \\
\hline 24 & Manufacture of basic metals & 0.24 \\
\hline 25 & Manufacture of fabricated metal products, except machinery and equipment & 0.11 \\
\hline 26 & Manufacture of computer, electronic and optical products & 0.36 \\
\hline 27 & Manufacture of electrical equipment & 0.17 \\
\hline 28 & Manufacture of machinery and equipment n.e.c. & -0.11 \\
\hline 29 & Manufacture of motor vehicles, trailers and semi-trailers & -0.15 \\
\hline 30 & Manufacture of other transport equipment & -0.14 \\
\hline 31 & Manufacture of furniture & -0.26 \\
\hline 32 & Other manufacturing & 1.00 \\
\hline 33 & Repair and installation of machinery and equipment & 0.94 \\
\hline 35 & Electricity, gas, steam and air conditioning supply & -0.44 \\
\hline 36 & Water collection, treatment and supply & 0.24 \\
\hline 38 & Waste collection, treatment and disposal activities; materials recovery & 0.61 \\
\hline 41 & Construction of buildings & 0.78 \\
\hline 46 & Wholesale trade, except of motor vehicles and motorcycles & 0.43 \\
\hline 47 & Retail trade, except of motor vehicles and motorcycles & 0.35 \\
\hline 52 & Warehousing and support activities for transportation & 0.18 \\
\hline 55 & Accommodation & 0.31 \\
\hline 56 & Food and beverage service activities & 0.28 \\
\hline 58 & Publishing activities & 0.59 \\
\hline 59 & $\begin{array}{l}\text { Motion picture, video and television programme production, sound recording and } \\
\text { music publishing activities }\end{array}$ & 0.34 \\
\hline 60 & Programming and broadcasting activities & 0.34 \\
\hline 61 & Telecommunications & 0.56 \\
\hline 62 & Computer programming, consultancy and related activities & 1.15 \\
\hline 63 & Information service activities & 0.56 \\
\hline 68 & Real estate activities & 0.32 \\
\hline 70 & Activities of head offices; management consultancy activities & 0.74 \\
\hline 71 & Architectural and engineering activities; technical testing and analysis & 0.10 \\
\hline 73 & Advertising and market research & 0.03 \\
\hline 74 & Other professional, scientific and technical activities & 0.23 \\
\hline 77 & Rental and leasing activities & 0.42 \\
\hline 79 & Travel agency, tour operator, reservation service and related activities & 1.01 \\
\hline 80 & Security and investigation activities & 0.09 \\
\hline 82 & Office administrative, office support and other business support activities & 0.46 \\
\hline
\end{tabular}

Table presents the Rajan and Zingales (1998) measure of dependence of external finance recomputed by Peia (2017) for a sample of US Compustat firms for the period 1990-1999. 


\section{UCD CENTRE FOR ECONOMIC RESEARCH - RECENT WORKING PAPERS}

WP19/03 Kanika Kapur: 'Private Health Insurance in Ireland: Trends and Determinants' February 2019

WP19/04 Sandra E Black, Paul J Devereux, Petter Lundborg and Kaveh Majlesi: 'Understanding Intergenerational Mobility: The Role of Nature versus Nurture in Wealth and Other Economic Outcomes and Behaviors' February 2019 WP19/05 Judith M Delaney and Paul J Devereux: 'It's not just for boys! Understanding Gender Differences in STEM' February 2019 WP19/06 Enoch Cheng and Clemens Struck: 'Time-Series Momentum: A MonteCarlo Approach' March 2019

WP19/07 Matteo Gomellini and Cormac Ó Gráda: 'Brain Drain and Brain Gain in Italy and Ireland in the Age of Mass Migration' March 2019

WP19/08 Anna Aizer, Paul J Devereux and Kjell G Salvanes: 'Grandparents, Mothers, or Fathers? - Why Children of Teen Mothers do Worse in Life' March 2019

WP19/09 Clemens Struck, Adnan Velic: 'Competing Gains From Trade' March 2019

WP19/10 Kevin Devereux, Mona Balesh Abadi, Farah Omran: 'Correcting for Transitory Effects in RCTs: Application to the RAND Health Insurance Experiment' April 2019

WP19/11 Bernardo S Buarque, Ronald B Davies, Dieter F Kogler and Ryan M Hynes: 'OK Computer: The Creation and Integration of AI in Europe' May 2019 WP19/12 Clemens C Struck and Adnan Velic: 'Automation, New Technology and Non-Homothetic Preferences' May 2019

WP19/13 Morgan Kelly: 'The Standard Errors of Persistence' June 2019

WP19/14 Karl Whelan: 'The Euro at 20: Successes, Problems, Progress and Threats' June 2019

WP19/15 David Madden: 'The Base of Party Political Support in Ireland: An Update' July 2019

WP19/16 Cormac Ó Gráda: 'Fifty Years a-Growing: Economic History and Demography in the ESR' August 2019

WP19/17 David Madden: 'The ESR at 50: A Review Article on Fiscal Policy Papers' August 2019

WP19/18 Jonathan Briody, Orla Doyle and Cecily Kelleher: 'The Effect of the Great Recession on Health: A longitudinal study of Irish Mothers 2001-2011' August 2019

WP19/19 Martina Lawless and Zuzanna Studnicka: 'Old Firms and New Export Flows: Does Experience Increase Survival?' September 2019

WP19/20 Sarah Parlane and Lisa Ryan: 'Optimal Contracts for Renewable Electricity' September 2019

WP19/21 Claes Ek and Margaret Samahita: 'Pessimism and Overcommitment' September 2019

WP19/22 David Madden 'BMI Mobility and Obesity Transitions Among Children in Ireland' September 2019

WP19/23 Martina Lawless and Zuzanna Studnicka: 'Products or Markets: What

Type of Experience Matters for Export Survival?' October 2019

WP19/24 Neil Cummins and Cormac Ó Gráda: 'Artisanal Skills, Watchmaking, and the Industrial Revolution: Prescot and Beyond' October 2019

WP19/25 Morgan Kelly, Cormac Ó Gráda and Peter Solar: 'Safety at Sea during the Industrial Revolution' October 2019 